\title{
Social capital in buyer-supplier relationships: A review of antecedents, benefits, risks, and boundary conditions
}

\author{
Mohammad Alghababsheh ${ }^{a, *}$, David Gallear ${ }^{\mathrm{b}}$

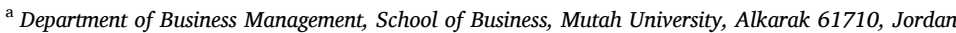 \\ ${ }^{\mathrm{b}}$ Brunel Business School, Brunel University London, Uxbridge UB8 3PH, United Kingdom
}

\section{A R T I C L E I N F O}

\section{Keywords:}

Literature review

Negative consequences

Outcomes

Social capital

Supplier

Supply chain

\begin{abstract}
A B S T R A C T
The concept of social capital advocates that the goodwill available from relations is a valuable resource that can facilitate collective actions. Although social capital has recently gained momentum in the buyer-supplier relationship (BSR) literature, there is a surprising lack of consensus about its antecedents, benefits, risks, and boundary conditions in such relationships. To address this void, a systematic literature review of seventy articles published in peer-reviewed journals between 2002 and 2018 was undertaken. The review identified and discusses two types of antecedents that can give rise to social capital in BSRs, namely intrafirm-level and relationship-level antecedents (i.e., structural and relational). It reveals that social capital can lead to a variety of benefits, in the form of direct performance improvements (e.g., operational) and relationship benefits (e.g., knowledge sharing), however that these benefits may vary depending on a number of boundary conditions in BSRs (e.g., contract specificity). The review also highlights that although social capital can generate benefits, it can also lead to risks that can undermine the performance and evolution of BSRs (e.g., reduced exploratory learning), suggesting a 'double-edged sword' effect. The paper concludes by summarizing current research gaps and outlining promising directions for future research.
\end{abstract}

\section{Introduction}

Social capital theory generally holds that individuals' or organizations' networks of relationships can be considered as valuable resources that facilitate collective actions (Adler \& Kwon, 2002; Inkpen \& Tsang, 2005; Pillai, Hodgkinson, Kalyanaram, \& Nair, 2017), providing them with "collectively-owned capital" which entitles them to credit in the various senses of the word (Bourdieu, 1986, p. 249). From sociology, social capital has attracted considerable scholarly attention across various social sciences disciplines to study different social relations at different levels (Kwon \& Adler, 2014; Nahapiet \& Ghoshal, 1998; Portes, 1998) ranging from the macro-level (i.e., nations) (Fukuyama, 2001), through the meso-level (e.g., communities (Putnam, 1995); networks (Burt, 1992); groups (Oh, Labianca, \& Chung, 2006); and interorganizational relationships (Inkpen \& Tsang, 2005)) to the microlevel (i.e., individuals) (Pena-López \& Sánchez-Santos, 2017). In business and management research, social capital has also occupied a prominent place (Kwon \& Adler, 2014; Lee, 2009), where it has been applied to understand management and organizational phenomena at different level of analysis (Payne, Moore, Griffis, \& Autry, 2011).
The notion of social capital is gaining momentum in the buyersupplier relationship (BSR) domain. This is arguably because social capital not only provides a useful and rich perspective to help explain and theorize the characteristics and nature of connections and cooperation in the relationship (Carey, Lawson, \& Krause, 2011; Krause, Handfield, \& Tyler, 2007; Roden \& Lawson, 2014), but also because as the accumulated goodwill that exists between buyer and supplier, social capital is capable of explaining and predicting many important behaviours and outcomes in the relationship (Lawson, Tyler, \& Cousins, 2008; Villena, Revilla, \& Choi, 2011). Prior research has suggested that social capital can underpin and contribute to effective BSRs by increasing knowledge exchange (Hung, Chen, \& Chung, 2014; Kim, Umanath, Kim, Ahrens, \& Kim, 2012), learning (Huikkola, Ylimäki, \& Kohtamäki, 2013; Kohtamäki \& Bourlakis, 2012), resilience (Johnson, Elliott, \& Drake, 2013), responsiveness (Grawe, Daugherty, \& Dant, 2012) and innovation (Kulangara, Jackson, \& Prater, 2016; Tsai, Joe, Ding, \& Lin, 2013), and by reducing opportunism (Lioliou \& Zimmermann, 2015; Wang, Li, Ross, \& Craighead, 2013). As such, examining social capital in the context of BSRs has important theoretical and practical implications.

The study of the social capital concept has relatively become a focal

\footnotetext{
* Corresponding author.

E-mail addresses: m.alghababsheh@mutah.edu.jo (M. Alghababsheh), david.gallear@brunel.ac.uk (D. Gallear).
} 
research stream within the BSR literature. Indeed, an increasing number of studies have focused on the antecedents, benefits, risks, and boundary conditions of social capital. However, while there is a growing interest in analysing a variety of antecedents of social capital, it is not easy to understand and differentiate these antecedents from an integrative perspective. The potentially reciprocal relationships between antecedents, social capital, and outcomes adds further difficulty in differentiating the antecedents from the outcomes of social capital and vice versa. Moreover, the increasing number of empirical studies examining the outcomes of social capital that have yielded contradictory results (e.g., Gelderman, Semeijn, \& Mertschuweit, 2016; Son, Kocabasoglu-Hillmer, \& Roden, 2016) suggests the need for new efforts to try to reach consensus on the outcomes of social capital and for clarifying the potentially complex relationship between them by taking into account boundary conditions. Furthermore, the clear prevalence of research on the positive outcomes of social capital (Villena et al., 2011) appears to have led to an underestimation of the negative consequences it can generate in the BSR, resulting in a lack of understanding of the nature of risks associated with social capital and when and why do they emerge. Despite these persisting challenges facing the further advancement of social capital research in BSRs, there is, surprisingly, the lack of an organized and integrative view to understanding the antecedents, benefits, risks, and boundary conditions of social capital and where future inquiry should be directed. Therefore, the first goal of this review was to synthesise and organize the current literature on social capital in BSRs research into an integrative framework of antecedents, benefits, risks, and boundary conditions of social capital. Based on this, our second goal was to identify current research gaps and detail important future research directions.

A systematic literature review (Tranfield, Denyer, \& Smart, 2003) and snowballing search (backward and forward) were carried out to identify all the relevant high-quality research work on social capital in BSRs. The review identified 70 papers published in peer-reviewed scholarly journals between 2002 and 2018. A descriptive analysis of the selected papers was undertaken to provide an overview profile of the social capital research in BSRs in terms of publication trend, methodological approach, research perspective (single- or dyadic- perspective), and the research's social capital dimension(s) focus. We then conducted a thematic analysis of the literature under the four main themes of antecedents, benefits, risks, and boundary conditions. Accordingly, this study contributes to the BSR literature in two important ways. First, the review comprehensively analyses and categorizes the antecedents, benefits, risks, and boundary conditions of social capital in BSRs, which are then developed into an integrative framework explicating the status of the current literature and providing a frame of reference for future scholarship to build on. Second, the study lays a foundation for future inquiry by identifying current research gaps and suggesting a number of important research directions covering different vital aspects of social capital in BSR research to help advance the theory and practice of BSRs.

The remainder of the paper is organized as follows. In the next section, a brief overview of social capital is provided before our methodology is discussed in Section 3. Section 4 presents the findings of the descriptive analysis and the antecedents, benefits, risks, and boundary conditions of social capital. Section 5 outlines important future research directions. The paper concludes by outlining the theoretical contributions and limitations of the study in Section 6.

\section{Social capital}

The broad, simple understanding of social capital as potential resources derived from social relations that facilitate collective actions (Adler \& Kwon, 2002; Inkpen \& Tsang, 2005; Uzzi, 1996) has been criticized for its vagueness and ambiguity regarding what aspects of social relations give rise to social capital, and conversely what constitutes social capital in relationships (Robison, Schmid, \& Siles, 2002). As a result, the concept has been subject to considerable scholarly work and debate to help to clarify the source and nature of social capital in social relations. As for the source, two perspectives have shaped our understanding of the specific aspects of social relations that generate social capital: the structural and the relational perspectives (Adler \& Kwon, 2002; Kostova \& Roth, 2003). Informed primarily by social network theories, the proponents of the structural perspective have emphasized the importance of features of relation structure (e.g., Baker, 1990; Putnam, 1995). On the other hand, the relational perspective has highlighted the role of relations content (e.g., norms and beliefs) (Adler \& Kwon, 2002; Kostova \& Roth, 2003). Bringing these two perspectives together, Adler and Kwon (2002, p. 23) proposed that "Social capital is the goodwill available to individuals or groups. Its source lies in the structure and content of the actor's social relations. Its effects flow from the information, influence, and solidarity it makes available to the actor". In respect of the nature of social capital, Nahapiet and Ghoshal's (1998) conceptualisation: "the sum of the actual and potential resources embedded within, available through and derived from the network of relationships possessed by an individual or social unit"; has been a key guide for considerable subsequent scholarly work. Nahapiet and Ghoshal (1998) argued that the essence of social capital can be captured through three dimensions: relational, cognitive, and structural.

Relational capital refers to the goodwill that exists between actors and is leveraged through a history of repeated interactions (Burt, 2000; Granovetter, 1992). It is a multi-faceted concept that includes the trust, obligation, identification, respect, and friendship that present in the relationships between partners (Kale, Singh, \& Perlmutter, 2000; Nahapiet \& Ghoshal, 1998). The cognitive capital dimension refers to "those resources providing shared representations, interpretations, and systems of meaning among parties" (Nahapiet \& Ghoshal, 1998; p. 244). Cognitive capital manifests when partners have shared language, codes, and system of meanings (Nahapiet \& Ghoshal, 1998), and aligned organizational culture, business philosophy, goals, and vision (Villena et al., 2011). It reflects a mutuality of expectations and similar perceptions that enable buyer and supplier to identify common and appropriate procedures for the achievement of mutual goals and tasks (Roden \& Lawson, 2014; Son et al., 2016). Structural capital represents the overall pattern of connections between partners (Nahapiet \& Ghoshal, 1998) in terms of the presence, frequency, and strength of social interactions (Tsai \& Ghoshal, 1998). These social interactions consist of social processes and activities established between buyer and supplier to coordinate and structurally embed the relationship (Alghababsheh \& Gallear, 2020; Roden \& Lawson, 2014).

Given its increasingly recognized important role in relationships, social capital is argued to share properties with other forms of capital (e. g., economic, physical, and human) (e.g., Adler \& Kwon, 2002; Lin, 2001; Nahapiet \& Ghoshal, 1998; Robison et al., 2002). Similar to other forms of capital, social capital is viewed as flexible and having utility for multiple purposes (Adler \& Kwon, 2002; Coleman, 1988; Robison et al., 2002). For instance, in an inter-organizational relationship, social capital facilities information sharing between partners (Kim et al., 2012), while also working towards curbing opportunism (Wang et al., 2013). Like other forms of capital, it can be an alternative and/or supplement to other forms of capital (Adler \& Kwon, 2002). As a substitute, individuals can compensate for lack of financial resources and human skills by having strong and valuable connections (Adler \& Kwon, 2002). As a supplement, social capital can enhance the productivity of economic capital by reducing transaction and monitoring costs (Robison et al., 2002). Social capital also requires maintenance like other forms of capital (Adler \& Kwon, 2002). A lack of continuous contacts and interactions between actors can reduce the strength of the social relations and thus its potential benefits (Robison et al., 2002). Like other forms of capital, social capital is an asset that needs investment to achieve benefits in the short and long-term (Bourdieu, 1986; Portes, 1998). It is a product of endless efforts, but by building it actors can obtain benefits such as access to information, power and solidarity (Adler \& Kwon, 2002). 
Social capital also has some properties that make it distinctive from other forms of capital. In contrast in particular to human capital which resides in the actors, social capital is embedded in a social relationship (Portes, 1998; Robison et al., 2002). Social capital is jointly owned by actors (Nahapiet \& Ghoshal, 1998) and no single actor has exclusive ownership rights to it (Burt, 1992). Thus, it can be argued that social capital 'vanishes' with the end of the relationship. Moreover, while physical capital is generated by transforming materials into systems and tools, and human capital is created by changes in individuals who develop their skills, social capital arises via changes in the relations among actors (Coleman, 1988). Furthermore, unlike other forms, social capital cannot be traded by people on an open market, not least because often it is 'inherited' in the social relationship (Leana \& Van Buren, 1999) or develops organically. Unlike other forms of capital, the benefits of social capital are generally not limited to the individual who possess it, they are also often accessible to all within the associated community (Kostova \& Roth, 2003). Social capital provides direct primary benefits to the 'owners' (Burt, 1997), and secondary benefits to those within the connected community without them necessarily having had to participate in its creation (Putnam, 1993).

\section{Review methodology}

This study follows the systematic literature review (SLR) methodology (Tranfield et al., 2003), which unlike the narrative review approach, provides a transparent and replicable synthesis of existing knowledge (Rousseau, Manning, \& Denyer, 2008). The SLR methodology involves three major stages: planning the review, conducting the review, and reporting and disseminating the findings (Tranfield et al., 2003). The planning stage, namely articulating the relevance and the urgent need to consolidate the existing knowledge on social capital in BSRs in terms of the antecedents, benefits, risks, and boundary conditions of social capital, were previously described in the introduction section of the paper.

In conducting the review stage, the search terms/strings set out in Table 1 were identified through a thorough reading of the theoretical foundations of social capital theory, and existing literature in BSRs and through discussions with expert peer academics. The terms/strings were used to search within the title, abstract, and keywords in the Scopus database for the relevant peer-reviewed articles published only in the English language up to and including 2018. The Scopus database is widely advocated as it not only contains the largest collection of published articles in the Operations, Industrial Marketing and Supply Chain Management fields, but also because it updates with newly published material on a daily basis, making it the most frequently updated database available. The initial search identified 397 articles of which 211 were excluded based on a close and detailed abstract analysis. A further four articles were discarded as they were not published in peer-reviewed scholarly journals listed in the Chartered Association of Business Schools (CABS) Academic Journal Guide (2018). This action was necessary to help to ensure the quality of the review (David \& Han, 2004) and CABS was used as the guide because it is widely regarded as a reliable measure of research rigour and quality (Johnsen \& Lacoste, 2016; Miemczyk, Johnsen, \& Macquet, 2012). Based on a full text scrutiny of the remaining 186, many other articles were excluded for several important

Table 1

Keywords used in the social capital literature search.

\begin{tabular}{|c|c|c|}
\hline Terms for Social capital & & Terms for BSRs \\
\hline $\begin{array}{l}\text { "Social capital" OR } \\
\text { "Relational capital" OR } \\
\text { "Relational embeddedness" OR } \\
\text { "Cognitive capital" OR } \\
\text { "Structural capital" OR } \\
\text { "Structural embeddedness" }\end{array}$ & AND & $\begin{array}{l}\text { "Business-to-business" OR "B2B" OR } \\
\text { "Supply chain" OR } \\
\text { "Buyer-seller" OR } \\
\text { "Buyer-supplier" OR } \\
\text { "Supplier" OR } \\
\text { "Purchasing" OR } \\
\text { "Procurement" OR } \\
\text { "Outsourcing" }\end{array}$ \\
\hline
\end{tabular}

reasons. First, studies that used social capital theory simply as an explanatory framework without examining its main constructs were excluded. Second, studies that did not examine the antecedents, benefits, risks, or boundary conditions of social capital were discarded given the stated aim and scope of this review. Third, studies focussing on the discussion of social capital in inter-organizational relationships in general terms without an exclusive focus on BSRs were also excluded. Forth, studies that explored the impact of intra-organizational social capital on BSR outcomes were also omitted (e.g., Ataseven, Nair, \& Ferguson, 2018; Stolze, Mollenkopf, Thornton, Brusco, \& Flint, 2018). Thus, after this detailed evaluation process had been completed, 62 articles remained and were selected for the review. To be assured that no relevant papers were left out, we followed Tranfield et al.'s (2003) advice and checked again by using cross-referencing search in addition to the systematic search. Specifically, backward and forward snowballing searches were used (see Greenhalgh \& Peacock, 2005; Jalali \& Wohlin, 2012). Although the literature is extremely limited in what criteria should govern the selection of key starting papers for a snowballing search (Jalali \& Wohlin, 2012), we used the articles by Cousins, Handfield, Lawson, and Petersen (2006), Lawson et al. (2008), Carey et al. (2011), and Villena et al. (2011) for two primary reasons. First, the articles represent some of the first explicit empirical examinations of social capital in the context of BSRs, and therefore they could serve as a starting point to identify early theoretical discussions on the topic. Second, these articles received the highest number of citations (as indicated by Google Scholar) among the articles selected in our review, and hence provided a comprehensive reference point from which to perform our forward snowballing. In the subsequent backward snowballing, we examined the reference list of these key articles to identify further relevant papers. We then also checked the reference lists of those additional papers to identify other relevant articles. We continued this process until no further relevant articles were found. In the forward snowballing, we traced the citations of the key articles using Google Scholar to identify further relevant articles. The snowballing (both backwards and forward) search process yielded 13 potential papers of which 5 were discarded (for the same reasons stated above), bringing the total to 70 papers (see the Appendix for full list).

Finally, in the reporting and disseminating the findings stage, a twopart report of the findings was produced following the recommendations of Tranfield et al. (2003). In the first part, a broad-ranging descriptive analysis of the extant literature in term of several categories, including publication trend over time, the methodological approach, the research perspective (single- or dyadic- perspective), and social capital dimension (s) examined was prepared. In the second part, a thematic analysis of the literature to draw insights pertaining to the antecedents, benefits, risks, and boundary conditions of social capital in BSRs was produced. This was completed by adopting a theme-centric analysis (Webster \& Watson, 2002), in which all papers were individually analysed and then grouped into a theme matrix according to their thematic focus. The following section presents the two-part report of the review findings.

\section{Analysis and findings}

\subsection{Descriptive findings of social capital research in BSRs}

\subsubsection{Publication trend over time}

The review shows that there has been a gradual growth in the volume of publications dealing with the antecedents, benefits, risks, and boundary conditions of social capital in BSRs between 2002 and 2018 (see Fig. 1). Although a steady but very limited flow of papers began to appear from 2006, real growth began in 2008 when five of the articles were published in one year, however followed by a decline in 2009 . Since then the number of articles appearing annually started to increase, although with fluctuations, peaking in 2017 (12 articles) and in 2018 (11 articles), respectively. 


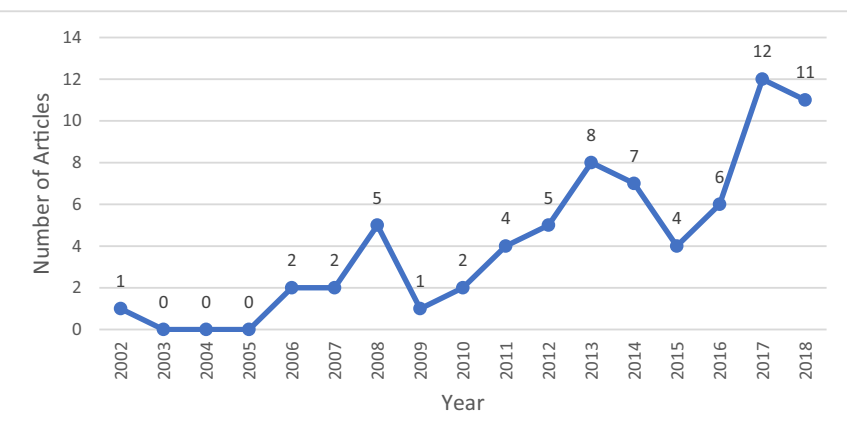

Fig. 1. Distribution of social capital research over the review period.

\subsubsection{Distribution of publications among journals}

The 70 social capital articles identified in the review were located across 40 different peer-reviewed journals (see Table 2). The scope of the majority of the journals is Industrial Marketing, Operations, and Supply Chain Management. Industrial Marketing Management recorded the highest number of social capital publications (6 papers; representing $8.57 \%$ ), followed by the Journal of Operations Management $(5 ; 7.14 \%)$ and the Journal of Business and Industrial Marketing (4; 5.71\%) and Supply Chain Management: An international journal (4; 5.71\%). Three articles (4.28\%) appeared in each of International Journal of Information Management, International Journal of Operations and Production Management, International Journal of Production Economics, Journal of Business Logistics, Journal of Supply Chain Management, and Journal of World Business. Two articles (2.85\%) were published in each of three other journals (Industrial Management \& Data Systems, International Journal of Production Research, and Production and Operations Management), and a single article was published in each of the remaining 27 $(38.57 \%)$ scientific journals (listed under 'other journals' as shown in Table 2).

\subsubsection{Methodological approach}

The extant research has employed different methodological approaches, including conceptual development, survey, and case study to examine the antecedents, benefits, risks, and boundary conditions of social capital in BSRs. It was clearly evident that the vast majority of the 70 studies used survey as their methodological approach (54 articles, representing $81.4 \%$ ). This is followed by case study $(10 ; 14.2 \%)$ (e.g., Huikkola et al., 2013) and then conceptual development (6, 8.5\%) (e.g., Carey \& Lawson, 2011). However, almost all of the empirical research

Table 2

Distribution of social capital papers in journals.

\begin{tabular}{llll}
\hline No. & Journal & $\begin{array}{l}\text { Number of } \\
\text { publication }\end{array}$ & $\%$ \\
\hline 1. & Industrial Marketing Management & 6 & 8.57 \\
2. & Journal of Operations Management & 5 & 7.14 \\
3. & Journal of Business \& Industrial Marketing & 4 & 5.71 \\
4. & Supply Chain Management: An international & 4 & 5.71 \\
& journal & & \\
5. & Int. Journal of Information Management & 3 & 4.28 \\
6. & Int. Journal of Operations and Production & 3 & 4.28 \\
& Management & & \\
7. & Int. Journal of Production Economics & 3 & 4.28 \\
8. & Journal of Business Logistics & 3 & 4.28 \\
9. & Journal of Supply Chain Management & 3 & 4.28 \\
10. & Journal of World Business & 3 & 4.28 \\
11. & Industrial Management \& Data Systems & 2 & 2.85 \\
12. & Int. Journal of Production Research & 2 & 2.85 \\
13. & Production and Operations Management & 2 & 2.85 \\
14. & Other journals & 27 & 38.57 \\
Total & & 70 & $\%$ \\
& $\quad$ & & 100 \\
\hline
\end{tabular}

adopted a cross-sectional design to data collection, which makes it difficult to demonstrate the existence and direction of causality between variables. This is because the cross-sectional designs involved collecting data on antecedents, social capital, outcomes, and boundary conditions at a single point in time without allowing time lags between them. Time lags between variables' measurement is necessary to allow the cause (social capital) to have an effect (outcomes). We located only two studies that had adopted a longitudinal design to data collection (Presutti, Boari, \& Fratocchi, 2016; Verwaal, 2017). Future scholarship should consider longitudinal design as a more effective approach to substantiate the existence of causality and to rule out the possibility of reverse causation between antecedents, social capital, and outcomes. Additionally, we encourage researchers to adopt longitudinal case study design to fully capture the dynamic nature of how social capital as a complex relational aspect embedded in the BSR develops over the BSR life cycle and its possible impact.

\subsubsection{Research perspective}

In this review, research perspective indicates the side(s) of the BSR from which the research data was collected to capture the level of social capital embedded in the relationship. The 64 empirical studies (of the 70 total) included in the review can be classified into three categories according to the research perspective, namely single-side perspective (buyer or supplier), dyadic perspective (buyer and supplier), multipleperspective (buyer plus tier 1 and 2 suppliers). The analysis revealed that 51 studies $(79.6 \%)$ adopted a single-side perspective, of which 35 were the buyers' perspective and 16 were the suppliers', while 11 studies $(17.1 \%)$ employed a dyadic perspective and only two studies (3.1\%) used a multiple-perspective. The scarcity of research using a dyadic or multiple-perspective approach can be mainly attributed to the significantly increased difficulty in gathering valid and reliable data from more than one side of the relationship and to the analytical difficulty in analysing and presenting data from paired/grouped relationships (Roh, Whipple, \& Boyer, 2013).

Although collecting data from a single side of the BSR has been an important research design in advancing the theory of social capital in the BSR literature, it may limit the validity of research conclusions since it attempts to captures a dyadic construct (such as social capital) that in practice is developed and shared between two parties from the perspective of only one side in the relationship (Son et al., 2016). A dyadic construct represents attributes or phenomena that exist across and involve multiple stakeholders (buyer-supplier) of interest (Flynn, Pagell, \& Fugate, 2018; Ketchen Jr, Craighead, \& Cheng, 2018; Roh et al., 2013). Asking only the buyer, for example, to report on the level of social capital (relational, cognitive, and structural) in the relationship with a supplier may not be appropriate as its perception may not match that of the supplier. This mismatch of buyer-supplier views on social capital may lead to opposing implications in the relationship (Villena \& Craighead, 2017). As such, future research should seek to adopt dyadicand/or multiple-perspective approaches to examine social capital in BSRs and to therefore enrich our understanding of how and why one partner's perception of social capital might be different from or similar to its partner's as a matter of course, not simply to address methodological issues and bias concerns (i.e. common method bias and single informant bias).

\subsubsection{Social capital dimension(s) focus in the prior research}

Social capital, as previously mentioned, can be regarded as a threedimensional concept comprising relational, cognitive, and structural capital. Although some of the studies reviewed treated social capital as a unitary construct, the majority of the studies conceptualised it as a multi-dimensional construct apparently to provide more insight regarding the complexity of its effects and the relative importance of each dimension in BSRs. Of the 70 articles reviewed, 64 (91.4\%) examined social capital in term of two or more different dimensions. Fig. 2 illustrates the cumulative frequency of the three different social 


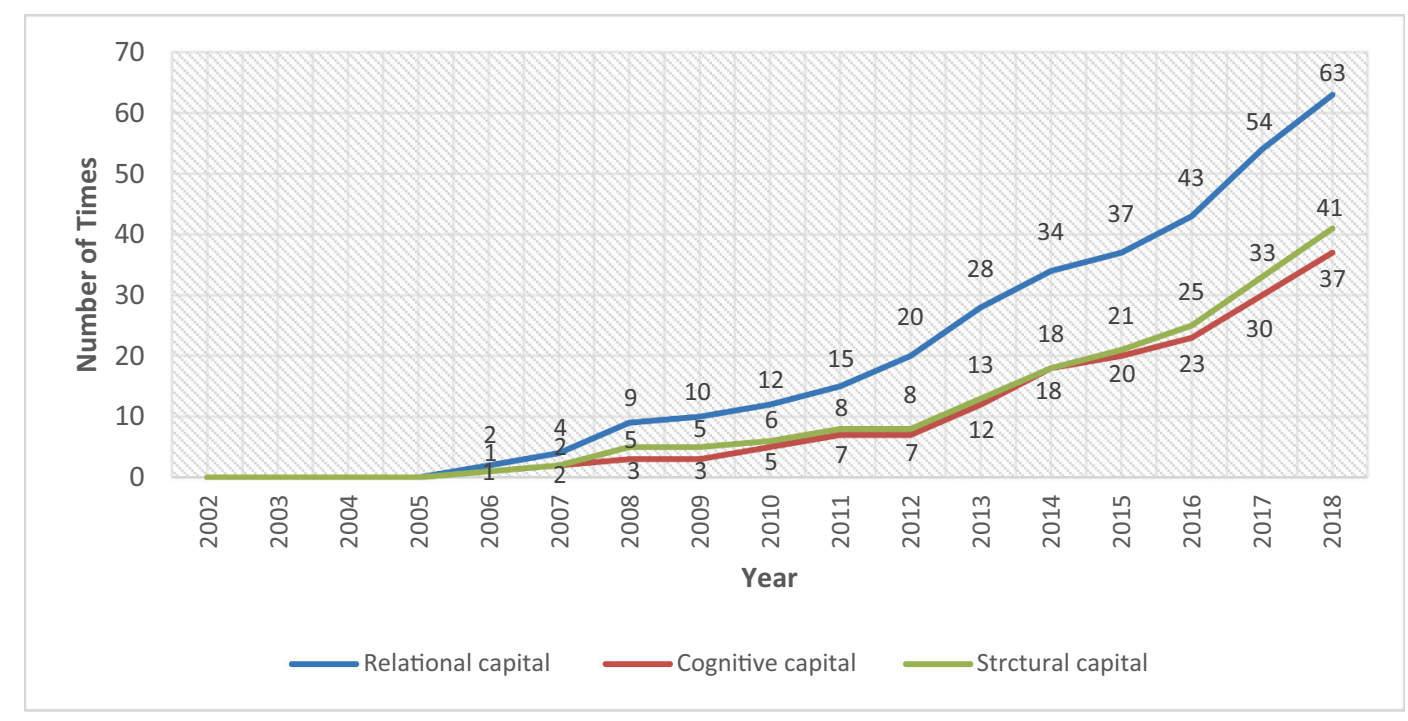

Fig. 2. Cumulative frequency of social capital research by dimension.

capital dimensions studied in the current research.

It was evident that relational capital had received the majority of the research attention (63 studies) (98.4\%). This was followed by structural capital, included within 41 (64\%) studies, and then cognitive capital included within $37(57.8 \%)$ studies. The relative under-representation of research on the cognitive dimension could be attributed to its more recent emergence following the re-conceptualisation effort of social capital in the seminal work of Nahapiet and Ghoshal (1998) which resulted in the three-dimensional typology. Another possible explanation for this relative under-representation is that cognitive capital has been perceived to have less of an influential impact on BRSs compared to relational and structural capital as is demonstrated in the majority of the current research.

To provide further insight on social capital dimension(s) focus, the reviewed studies were broken down according to whether they examined a single, a two, or a three-dimensional model of social capital. Twenty-two $(34.3 \%)$ incorporating a single social capital dimension (relational or cognitive or structural) were identified with nearly all focused on relational capital. Six (9.3\%) studies incorporating a twodimensional model of social capital (relational and cognitive, or relational and structural, or cognitive and structural) were identified with the majority examining relational and structural capital together. Finally, 35 studies (54.6\%) examined the three-dimensional model of social capital, the majority of which were published in the more recent years, suggesting a trend towards greater acceptance of, and integrating the three dimensions into, a holistic model facilitating the examination of the relative and unique importance of each dimension in BSRs.

\subsection{Social capital: antecedents, benefits, risks, and boundary conditions in BSRs}

This review was framed around the antecedents, benefits, risks, and boundary conditions of social capital in BSRs. In general, it was observed that most of the papers set out to explore the benefits of social capital to BSRs, while less effort had been devoted to exploring the antecedents, risks, and boundary conditions. A classification of the 70 articles included in this review according to the four aspects is provided in the Appendix.

\subsubsection{The antecedents of social capital in BSRs}

We identified that social capital in BSRs is developed by intrafirmlevel antecedents and relationship-level antecedents. Intrafirm-level antecedents refers to those antecedents that exist within the internal environment of either the buyer or the supplier, while relationship-level antecedents refers to those antecedents that manifest in the relationship between buyer and supplier. It was evident that no intentional or organized investment, resources, or activities that give rise to a stock of social capital had been explored in the BSR literature. This supports the notion that social capital is often a by-product of other activities in the relationship rather than a core product sought from a deliberately designed process (Nahapiet \& Ghoshal, 1998). It is also worth noting that the current research also suggests that social capital dimensions can be antecedents to each other. In particular, a common agreement seems to have developed that structural capital facilities the development of both relational and cognitive capital, while cognitive capital also fosters relational capital (e.g., Carey et al., 2011; Horn, Scheffler, \& Schiele, 2014; Li, Ye, \& Sheu, 2014; Lioliou \& Zimmermann, 2015; Preston, Chen, Swink, \& Meade, 2017; Roden \& Lawson, 2014; Sukoco, Hardi, \& Qomariyah, 2018).

4.2.1.1. Intrafirm-level antecedents. The process of developing social capital in a buyer-supplier dyad appears to commence by creating the necessary preconditions in the internal environment of the partners. Yu and Huo (2018) revealed that building internal relational capital among different organizational functions can facilitate the establishment of relational capital with suppliers, which in turn improves suppliers quality integration. Horn et al. (2014) provided more explanation of this link by demonstrating that internal relational capital facilitates internal integration (cross-functional collaboration), which in turn promotes the development of cognitive and structural capital with suppliers. Both cognitive and structural capital lead to the development of relational capital, which enhances external integration (supplier integration). Bernardes's (2010) results suggest that the presence of a strategic supply chain function contributes to the development of relational and cognitive capital, in turn leading to an increase customer responsiveness. In another study, Shou, $\mathrm{Hu}$, and $\mathrm{Xu}$ (2018) explained how high quality and skilled human capital contributes to the development of relational capital that can increase supplier intelligence integration.

4.2.1.2. Relationship-level antecedents. The relationship-level antecedents of social capital in BSRs reflect a wide range of aspects of BSRs, but can be grouped into two main types, namely structural antecedents and relational antecedents. Structural antecedents reflect those aspects relating to relationship structure and interactions, whilst relational antecedents represent those relating to the relational content, behaviours, and characteristics manifested in BSRs. 
A variety of structural antecedents have their effects been assessed on the development of social capital. However, almost all the existing research has focused on the role of the structural antecedents on building relational capital. Relational capital was reported to flourish in BSRs where suppliers are geographically located (relatively) close to buyers (Lawson et al., 2008). Supplier integration is highlighted to play a significant role in developing relational capital in the relationship (Lawson et al., 2008; Petersen, Handfield, Lawson, \& Cousins, 2008). In their study, Grawe et al. (2012) revealed that organizational implantation (an on-site representative of the other party) increases customers' commitment towards logistics service providers through leveraging relational capital and increased responsiveness. Taking the supplier's perspective, Blonska, Storey, Rozemeijer, Wetzels, and de Ruyter (2013) also indicated that two types of supplier development (i.e. capability development and assessment) contribute to buyer-supplier relationships by building relational capital, which in turn, increases both buyer and supplier benefits. Similarly, Lee (2015) found that monitoring suppliers (i.e. evaluation, audit, and certification) and collaborating with suppliers (i.e. information sharing and joint development) - as green supply chain management practices - leveraged relational capital and structural capital in the buyer-supplier relationship. Likewise, Cousins et al. (2006) revealed from their data of 111 buyers in the UK that informal socialisation, but not formal socialisation, led to the development of relational capital, which in turn led to improved supplier relationship outcomes.

The study of relational antecedents of social capital in BSRs was found to be extremely limited in the current literature. However, the existing research has examined the impact of this type of antecedents on leveraging only the relational and structural capital dimensions. Milosevic (2016) examined the impact of buyers' reliance (i.e. ability to fulfil contractual obligations) and relational bonding norms on the development of relational capital and how formal and informal institutional distance moderates these relationships. The results suggest that both reliance and relational bonding norms positively enhance relational capital. However, as formal institutional distance decreases, buyers' reliance has more impact on the development of relational capital. On the other hand, as informal institutional distance decreases, relational bonding norms have more effect on the development of relational capital. More recently, Kim, Lee, and Lee (2017) revealed that fairness in the relationship and referent power of buyers (e.g., respect, and role model behaviour) increased the development of relational and structural capital. Conversely, buyers' coercive power that is often associated with or signals potential penalties, was negatively related to structural capital.

\subsubsection{Benefits of social capital in BSRs}

The existing literature reveals that social capital dimensions can lead to a variety of desirable benefits in BSRs. These benefits of social capital can be attained from its direct outcomes and mediating and moderating effects. We were able to identify and distinguish between two broad types of benefits of social capital embedded in BSRs: performance benefits and relationship benefits. It is noteworthy that some of the benefits have a reciprocal relationship with social capital. In other words, these benefits can also operate as antecedents to social capital.

4.2.2.1. Performance benefits. The selected literature has revealed positive impacts of social capital dimensions on the strategic, financial, operational, innovation, and environmental performance of both buyer and supplier. However, the literature shows inconsistent results regarding the impact of specific social capital dimension(s) on specific types of performance. For example, Carey et al. (2011) found that only relational capital directly improves buyers' cost and innovation performance. However, Krause et al. (2007) found that all three dimensions of social capital had a positive impact on buyer's operational performance outcomes, albeit to differing degrees. Specifically, while relational capital was more important in achieving cost savings, cognitive and structural capital were more vital in achieving improvements in quality, delivery, and flexibility. Supporting the importance of all three dimensions of social capital, Villena et al. (2011) and Son et al. (2016) revealed that the development of all three was positively related to both strategic and operational performance. However, Gelderman et al. (2016) examined the impact of the all three dimensions of social capital and revealed, surprisingly, that only cognitive capital improved strategic performance. Examining the suppliers' perspective, Kohtamäki, Partanen, and Möller (2013) uncovered that relational capital directly leads to an increase in supplier's profit and indirectly through increasing the effectiveness (i.e. facilitating resource and information exchange) of supplier's R\&D services. In another study from suppliers' perspective, Lee (2015) found both relational and structural capital increase suppliers' environmental and operational performance.

4.2.2.2. Relationship benefits. The development of social capital can be seen to contribute to BSRs by enhancing a variety of benefits at the relationship level. The reviewed research effort has demonstrated the impact of social capital dimensions on outcomes other than performance, or on variables that serve as antecedents to performance.

A number of scholars have examined how social capital dimensions affect partners' exchange of knowledge and information, however different social capital dimensions have been found to play different roles on different forms of knowledge and information sharing. In their examination of 82 buyers in electronic manufacturing services, Kim et al. (2012) found that social capital facilitates knowledge exchange between buyer and supplier. Similarly, Hung et al. (2014) found that, among the three dimensions of social capital, cognitive capital facilitates both knowledge inflow and outflow, while structural capital facilitates only knowledge inflow. Surprisingly, relational capital had no influence on knowledge inflow or outflow. In another study, Li et al. (2014) found that only relational and cognitive capital directly improves information sharing in terms of content and quality, while structural capital facilitates information sharing indirectly through developing relational and cognitive capital.

The impact of social capital on knowledge in BSRs goes beyond mere exchange to facilitate its acquisition and utilisation. For instance, Zhang, Guo, and Zhao (2017) found that social capital fosters knowledge acquisition (i.e. the ability to identify and obtain knowledge that is crucial to one partner's operations from its partner) and knowledge combination (i.e. the ability to synthesise current and previously acquired knowledge). Wang and Li (2017) provided more insight by explicating which social capital dimensions lead to the development of which type of absorptive capacity. They revealed that relational capital is positively related to both the development of potential absorptive capacity (PAC) (knowledge acquisition and assimilation) and realised absorptive capacity (RAC) (knowledge transformation and exploitation), whilst structural capital is only positively related to the development of supplier PAC. Surprisingly, Wang and Li (2017) found that cognitive capital had no impact on enhancing either of these capabilities, which contradicts Unal and Donthu's (2014) study which reported that outsourcing partners' cognitive capital led to the development of absorptive capabilities and subsequently partnership performance.

The development of social capital has been found to foster learning in BSRs. Chang and Gotcher (2007) reported, based on 118 suppliers' perspectives, that relational capital enhances BSR learning leading to enhancement of their joint capability. Kohtamäki and Bourlakis's (2012) investigation of 195 customer-supplier relationships revealed that social capital facilitates relationship learning. Similarly, Huikkola et al. (2013) suggested that relational capital enables joint learning by enhancing knowledge sharing and effective collaboration, opening twoway dialogue, developing joint sense-making and creating commitment to knowledge implementation and integration in buyer-supplier collaboration R\&D efforts. Li's (2010) study provided a more comprehsive perspectvie by linking different social capital dimensions to a variety of learning capabilities. Li (2010) demonstrated that relational 
capital and cognitive capital enhanced both exploitative and exploratory learning, whilst structural capital had a positive effect only on exploratory learning.

Social capital dimensions have also been found to contribute to BSRs by generating other relationship outcomes including facilitating integration (Horn et al., 2014; Shou et al., 2018; Yim \& Leem, 2013; Yu \& Huo, 2018), increasing supply chain resilience (Johnson et al., 2013), risk identification (Fan \& Stevenson, 2018), responsiveness (Grawe et al., 2012), customer knowledge development (Tsai et al., 2013), commitment to innovation (Tsai et al., 2013), innovation capability (Kulangara et al., 2016), and technological capability (Tseng \& Chen, 2014), and by reducing opportunism (Hartmann \& Herb, 2014; Lioliou \& Zimmermann, 2015; Wang et al., 2013).

\subsubsection{Risks of social capital in BSRs}

The current literature has predominately focused on the presumed positive consequences of social capital. A growing but limited research has investigated risks or negative consequences of social capital, suggesting a double-edged sword effect. It can be observed that this research dealt with three important and insightful aspects to understand the risks of social capital, including the nature of the risks, when and why do they emerge.

The current literature has identified a number of downsides associated with the presence of an excessive level of social capital in BSRs. For example, Chou, Chen, and Pan (2006) revealed that although the social capital that buyers have with existing suppliers can facilitate information technology (IT) outsourcing and collaboration, it can undermines the rationality and objectivity of outsourcing decisions by reducing the likelihood of considering better alternative IT suppliers. Similarly, longterm social capital built with current suppliers also leads buyers to exclude other suppliers and restrict the flow of information between buyers and suppliers (Erridge \& Greer, 2002). Social capital can also inhibit knowledge exchange and reduce exploratory learning in BSRs (Handoko, Bresnen, \& Nugroho, 2018; Wang, Terziovski, Jiang, \& Li, 2017).

Social capital turns into harmful resource negatively affecting BSRs when it overly accumulates in the relationship. A number of the studies have suggested that too much social capital is as bad as too little, and thus contend that a moderate level of social capital can yield its best performance enhancement contribution in BSRs. For instance, Yang (2009) observed that alliance performance in BSRs increases as relational capital increases, however, performance starts to deteriorate as relational capital reaches excessive levels in the relationship. Similarly, Villena et al. (2011) warned of the 'dark side' of social capital when they found an inverted curvilinear relationship between relational capital and both operational and strategic performance, and between structural capital and operational performance. Son et al. (2016) supported this notion, revealing that whilst the accumulation of social capital dimensions increases strategic and operational performance to a certain level, performance can then decline with an over accumulation in the relationship. More recently, Cho, Bonn, Giunipero, and Jaggi (2017) also found that whilst social capital drives new product development (NPD) between buyer and supplier to a certain level, further increase of social capital beyond this level has the effect of reducing it.

The idea that a 'high' level of social capital can be detrimental to BSRs can be explained by the fact that when buyer and supplier interact much more frequently and/or overly trust each other, the likelihood of opportunism can increase (Villena et al., 2011). Additionally, as social capital increases, relationship learning and the flow of information and new innovative ideas can decrease (Cho et al., 2017; Chou et al., 2006) due to "groupthinking" (Qian, Yang, \& Xue, 2018).

\subsubsection{The boundary conditions of social capital in BSRs}

The previous section highlighted that social capital can lead to a variety of outcomes in BSRs. However, an emerging research stream within the body of literature reviewed has emphasized that the effects of social capital might not be universally applicable. The research has suggested that the effects of social capital hold or vary under certain conditions and circumstances.

The impact of social capital on relationship outcomes appears to vary according to firm type and role (position) in the supply chain. For example, in servitized firms, social capital has been found to both directly, and indirectly through knowledge combination, enhance operational performance, however in traditional manufacturing firms it only improves operational performance indirectly through facilitating knowledge acquisition (Zhang et al., 2017). Leem and Rogers (2017) reported that for the supplier and distributor, only relational and cognitive capital positively influenced performance, whilst for the manufacturer and logistics, provider all the three dimensions of social capital improved performance.

The type and structure of governance in BSRs also alter the outcomes of social capital. For instance, when legal bonds (formal governance) are used to govern the relationship, relational capital leads to higher buyer cost and innovation improvements (Carey et al., 2011). Likewise, Wang et al. (2017) revealed that relational and structural capital positively affect exploitative learning but negatively affect exploratory learning. However, under higher levels of contract specificity in the relationship, the positive impact of relational and structural capital on exploitative learning is stronger and its negative impact on exploratory learning is stronger.

Social capital has frequently been reported to play a vital role in facilitating and increasing knowledge exchange in BSRs. However, this crucial role has been observed to reduce or be absent depending on whether partners possess knowledge complementarities and on the length of their relationship. Kim et al. (2012) reported that with high knowledge complementarities between partners, social capital negatively affects knowledge exchange, whereas with low knowledge complementarities, social capital has no influence on knowledge exchange. Similarly, relational capital has been found to increase the transfer of knowledge from the buyer to the supplier in young relationships and in turn lead to greater supplier cost efficiency and innovation, however this influence decreases in lengthier BSRs (Preston et al., 2017).

The outcomes of social capital also differ based on the distance and the degree of symmetry between buyer and supplier and their international experience. Social capital dimensions have been found to be positively related to a supplier's foreign economic performance (Presutti et al., 2016), however the positive impact of relational and cognitive capital is stronger with low levels of psychic distance, while the positive impact of all three social capital dimensions is evidenced only for high geographical distance between the partners. Tseng and Chen (2014) found that relational capital increases a buyer's technological capability as its international experience increases. A recent interesting insight reported by Villena and Craighead (2017) suggests that relational capital reduces opportunism only when both buyer and supplier share the same levels of relational capital. Villena and Craighead (2017) added that buyers observe reduced benefits and suppliers perceive slightly improved benefits when it is the suppliers that have higher levels of relational capital.

A wide range of antecedents, benefits, risks, and boundary conditions were identified in the existing research on social capital in BSRs. The findings have been developed into an integrative framework of social capital in BSRs which is presented in Fig. 3. The framework illustrates that structural and relational antecedents in BSRs can create social capital. This is consistent with the two dominant perspectives of the sources of social capital in social relations as was discussed in Section 2. The structural antecedents represent interactions and closeness between buyer and supplier, while the relational antecedents reflect the content (nature) of BSRs, such as norms. The framework also illustrates that social capital can generate benefits (performance and relationship benefits) to BSRs, but can also lead to negative consequences, suggesting a 'double-edged sword' effect of social capital in the BSR context. The framework also underscores that the benefits of social capital in BSRs are 


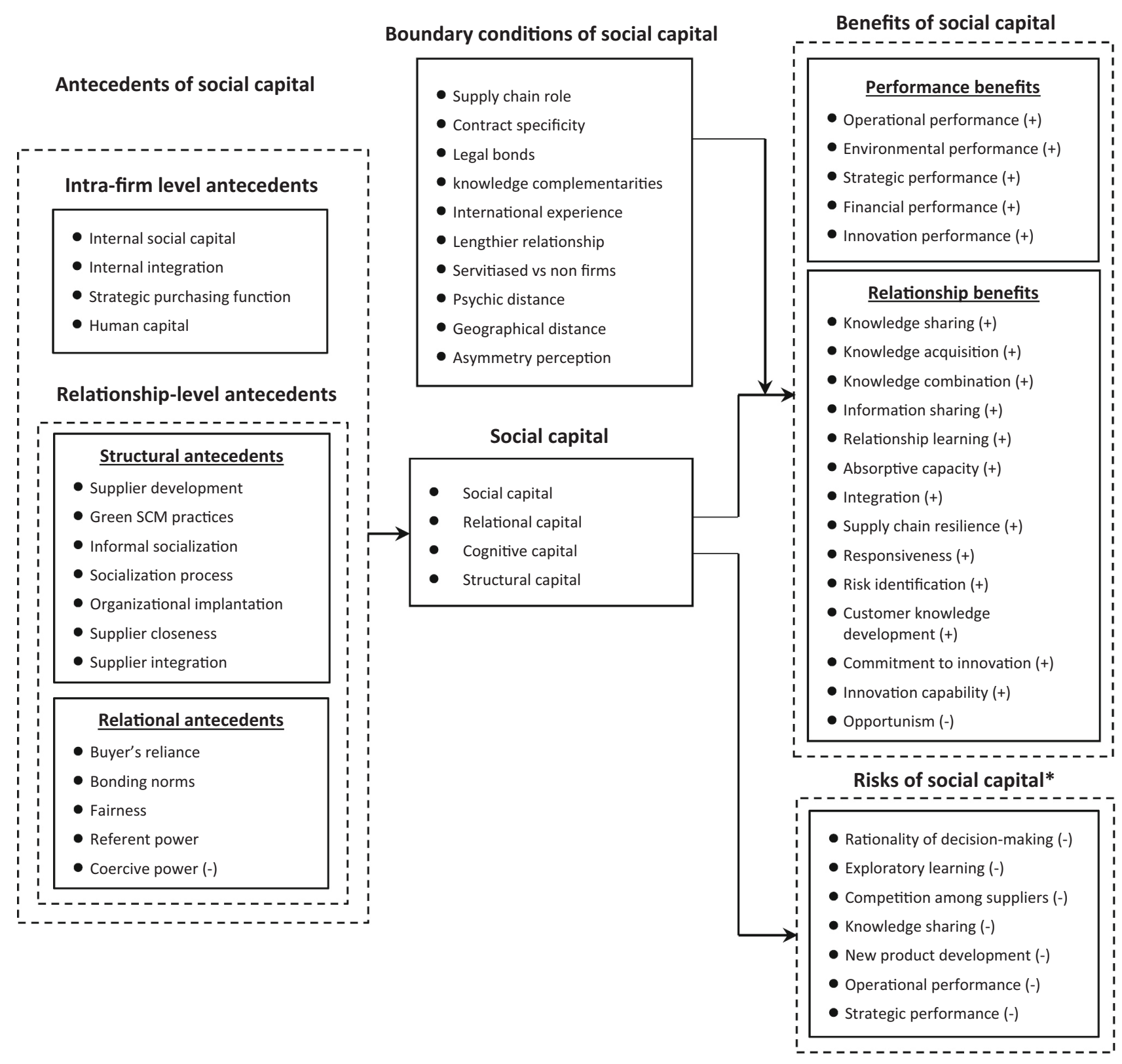

Note: (+) detonates positive relationship; and (-) indicates negative relationship

* Risks are more evident when social capital is at higher levels in the relationship

Fig. 3. An integrative framework of social capital in BSRs.

not universally applicable. In other words, the impact of social capital on relationship outcomes varies depending on certain conditions and contexts.

\section{Future research directions}

In addition to identifying and organizing the antecedents, benefits, risks, and boundary conditions of social capital in BSRs, this review aims to provide a foundation for future inquiry by identifying current gaps in the extant literature and suggesting important research directions to stimulate further theoretical and empirical work which can advance both the theoretical basis and the practice of BSRs.

\subsection{Future research related to the antecedents of social capital}

The antecedents of social capital have received limited attention compared to its outcomes in the extant literature. Although social capital is widely believed to flourish as the "distance" between actors decreases (Nahapiet \& Ghoshal, 1998), examining if this holds true and is applicable, and to what extent, in BSRs, has received scant attention. "Distance" in BSRs comprises three aspects: geographical distance, cultural distance, and organizational distance (Awaysheh \& Klassen, 2010). Geographical distance refers to the physical spatial separation between buyer and supplier; cultural distance refers to the extent to which buyer and supplier operate in regions, countries or other contexts with similar customs and values; and organizational distance is said to decrease as the number of tiers between buyers and suppliers reduces (Awaysheh \& 
Klassen, 2010). When all types of distance decrease, it is expected that buyer and supplier will face fewer obstacles to frequent interaction, leading to greater potential for the development of social capital. However, the extent to which these different types of distance affect the development of social capital individually, or in different combinations, is not yet known.

An observation that has emerged from our review is that the structural antecedents of social capital have received more attention to date compared to the relational antecedents, yet it has been argued that the quality of relations between actors is likely to have a profound effect on the development of social capital. An important research avenue therefore is to explore how the important relational aspect of perceived justice in BSRs can create the necessary conditions for the development of social capital. Justice is increasingly regarded as a foundation on which BSRs are established, continue, and evolve (Alghababsheh, Gallear, \& Rahman, 2018). Although Kim et al.'s (2017) more recent study has examined the impact of fairness on the development of relational and structural capital, the study did not differentiate among the different dimensions of inter-organizational justice (i.e. distributive, procedural, and interactional) and thus did not disentangle the unique role of each of the inter-organizational justice dimensions on leveraging social capital. The different inter-organizational justice dimensions may have differing impacts on leveraging the different social capital dimensions as each justice dimension is associated with different aspects (economic, structural, and social) of the BSR (Luo, Liu, Yang, Maksimov, \& Hou, 2015). Greater insights can be gained by exploring which justice dimension can lead to the development of which social capital dimension: we might expect to find for example, that interactional justice has a strong effect on leveraging all types of social capital, whilst distributive and procedural justice has a more restricted effect, creating and maintaining specific dimensions only.

\subsection{Future research related to the benefits of social capital}

In examining the impact of social capital dimensions on various BSR outcomes, growing research has attempted to extend our understanding by examining the impact of the interaction effect among these dimensions on outcomes (e.g., Qian et al., 2018). Two views are evidently emerging on the impact of the interaction effects, namely the complementary and substitutive view. According to the complementary view, a greater level of outcome can be realised from one dimension of social capital when another dimension is also present, compared to the level attainable if the other was not present. On the other hand, the substitutive view argues that the same level of outcome can be achieved from each social capital dimension regardless of the level of the others. Although the former view proposes that higher levels of outcome can be realised under different social capital dimension interaction conditions, research to date on the complementary view has not yet established which specific dimension(s) buyers and/or suppliers should seek to leverage in the relationship to realise the maximise outcome. This is problematic because this lack of knowledge may lead managers to direct their attention and investment towards dimension(s) that only generate very slight outcome improvements. We propose that this needs to be investigated, and moreover that in doing so it would be useful to also examine the salience of the constraining factor model (CFM) (see Narasimhan, Narayanan, \& Srinivasan, 2013; Siemsen, Roth, \& Balasubramanian, 2008). According to the CFM, the buyer and supplier can realise a greater outcome level by leveraging the social capital dimension which presently has the lowest level in the relationship, rather than leveraging any, or all of the dimensions (Narasimhan et al., 2013). In other words, when the level of one of the dimensions is low relative to the others, improving the other two dimensions will not achieve further significant performance improvement (Narasimhan et al., 2013).

It was evident from our review (see Fig. 2) that the relational dimension of social capital has received almost twice as much attention over the review period as the cognitive or structural capital dimensions.
This imbalance in focus indicates that a significant number of studies have not considered the three dimensions simultaneously, and thus have failed to sufficiently disentangle the unique role and distinct importance of each dimension compared to the others in BSRs. Future research should therefore seek to employ more nuanced investigations by comprehensively including all three individual dimensions in their investigations to provide greater insight into the relative importance of each dimension in BSRs. Moreover, our understanding can be deepened further by investigating the relative importance or impact of the three different social capital dimensions on different aspects of each specific outcome area in BSRs. This can advance current theory by identifying if a specific dimension of social capital has a stronger effect on one aspect of the outcome variable, while another dimension has a stronger effect on a different aspect of the same outcome variable. For instance, it would be useful to know if one of the social capital dimensions has a stronger facilitating role on the implementation of assessment-based sustainable supply chain management (SCM) practices compared to the level it has on collaboration-based sustainable SCM practices.

\subsection{Future research related to the risks of social capital}

The review revealed that social capital can have both favourable and, under certain circumstances, unfavourable effects (or consequences) in BSRs. While our understanding of the positive implications of social capital is advancing relatively rapidly, our understanding of its negative implications is much more underdeveloped. The greater attention towards the positive consequences of social capital is understandable and moreover is likely to have been influenced by the prevalence of somewhat 'one-sided' definitions of social capital which presume and recognise it as a resource with only positive outcomes without acknowledging its potential for negative outcomes (Adler \& Kwon, 2002). However, while the majority of previous research efforts on the negative consequences of social capital have been dedicated to understanding the nature of these negative consequences, our understanding of why and how social capital might generate such negative consequences is extremely limited. Further research is therefore needed to look deeply into why and how social capital might adversely affect key aspects of BSR development, for example innovation or absorptive capacity, by exploring the underlying mechanisms and conditions (possible mediating variables) through which social capital translate into potential negative consequences. This is highly important and theoretically insightful because understanding the mechanisms through which social capital negatively affects BSR outcomes can provide the ground for a better identification and understanding of the mechanisms (possible moderating variables) through which the negative impacts can be prevented or mitigated.

The review has already highlighted that negative effects of social capital can emerge when social capital in BSRs reaches excessive levels. Future research is therefore recommended to explore how the development of social capital can be better managed to stop it from reaching the excessive levels that precipitate negative effects. However, it is important to note that this analysis must include a comprehensive understanding of what constitutes an excessive level of social capital in different contextual circumstances. We would contend that whether a certain level of social capital is excessive may, in particular, depend on cultural factors, for example the prevalence of collectivism over individualism or vice versa. A high level of social capital for one culture might be seen as moderate or even low in another, and consequently the same level of social capital might lead to positive consequences in one culture but to negative consequences in another. As such, this line of enquiry seems particularly pertinent in the context of cross-border BSRs.

\subsection{Future research regarding the boundary conditions of social capital}

The review established that to date the examination of moderators in the extant literature has generally been very limited. Two types of 
moderators have been studied, namely the moderators of social capital antecedents, and the moderators of social capital outcomes. While the former can increase our understanding of the circumstances under which antecedents can (or cannot) augment the development of social capital, the latter provide insights regarding the conditions under which social capital outcomes can (or cannot) be realised or maximized. However, the former has received much less attention. Only two studies appear to have been undertaken, those of Roden and Lawson (2014) and Carey and Lawson (2011). Therefore, future research should be directed towards exploring more moderators of social capital antecedents to develop a more complete understanding of the conditions under which social capital develops and evolves in BSRs, for example how power (i.e., the ability of one party to influence another) in BSRs would moderate the relationship between antecedents and social capital development. In this vein, we would suggest that French and Raven's (1959) classification of five different types of power (expert, referent, coercive, legitimate, and reward) could be used as it explicates the perceived different reasons (or sources) why one party may influence or control another (Benton \& Maloni, 2005; Maloni \& Benton, 2000). As such, adopting this nuanced view of power will help in determining whether specific types of power would support (or undermine) the development of the different forms of social capital (i.e., relational, cognitive, and structural). For instance, the use of coercive power by buyer whereby administrating punishment to supplier may erode the leverage of relational capital in the relationship. On the other hand, buyer's legitimate power (i.e., when one party believes that its partner has naturel right to influence it) as perceived by supplier may lessen the negative impact of some actions by buyer on the development of social capital. The effect of these type of powers could be further scrutinised by differentiating between mediated (expert and referent) and non-mediated (coercive, legitimate, and reward) power. In general we expect that mediated power, which represents the competitive and negative uses of power (Benton \& Maloni, 2005), would hinder the development of social capital, while nonmediated power, which are more relational and positive in orientation, would create the necessary condition to promote the rise of social capital.

Whilst previous research has highlighted the importance of a contingency approach (two-way interaction), accepting the premise that social capital outcomes are context-specific, to studying the link between social capital and outcomes over the dominant universal (maineffects-only) approach, greater insights into social capital-outcomes link could be gained through exploring how different characteristics or attributes of BSRs simultaneously effect this link. This can be accomplished by adopting a configurational approach (three-way interaction), which would involve the simultaneous and joint consideration of the different BSR characteristics and attributes, for example power structure and relationship length. Thus, the configuration approach, which helps to more accurately reflect the complexity of BSRs, can advance the current knowledge by not only providing a deeper understanding of which BSR configurations underpin social capital's positive effect, but also by identifying which social capital dimensions are more salient than others under different configurations of BSR characteristics.

\section{Conclusions}

\subsection{Theoretical contribution}

This paper set out to explore the antecedents, benefits, risks, and boundary conditions of social capital in BSRs via a systematic survey of the current literature. In total, 70 papers published in peer-review journals between 2002 and 2018 were identified and have been analysed both descriptively and thematically. In the descriptive analysis, the articles were analysed according to publication trend over time, the methodological approach, research perspective, and social capital dimension(s) examined. In the thematic analysis, the current literature was analysed to explore the antecedents, benefits, risks, and boundary conditions. This study contributes to BSRs literature in two important ways. Its first contribution is the identification and categorization of antecedents, benefits, risks, and boundary conditions of social capital in BSRs into an integrative framework (Fig. 3), which has advanced our understanding of the current state of the social capital research in the context of BSR, and can also serve as a frame of reference to stimulate and guide further scholarship. Based on the review, a wide range of antecedents that give rise to social capital in BSRs have been identified and organized into two main types, including intrafirm-level and relationship-level antecedents (i.e., structural and relational). This has not only increased our understanding of the antecedents from an integrative perspective, but also enabled the differentiation of the antecedents from the outcomes of social capital. Our paper also identified and differentiated between performance and relationship benefits that can be attained for buyer and supplier. This review also highlighted the potential risks of social capital in BSRs by consolidating the fragmented and limited literature on the "dark side" of social capital. This has deepened our understanding of the nature of these risks and when and why do they emerge. Our review also identified a number of boundary conditions (moderators) of social capital outcomes related to different aspects of BSRs. This has enhanced the clarity of the social capitaloutcomes link by revealing that certain benefits of social capital are context-specific.

The second main contribution of this study is the identification of current research gaps and extrapolating important future research directions. In the previous section, we set out multiple avenues for further research covering various aspects of social capital in BSRs which will provide much needed and timely enrichment of the knowledge of BSRs. We urged scholars to adopt a dyadic perspective when examining social capital in BSRs to address potential biases that may result when only buyer or supplier reporting on the level of social capital in the relationship is present, and in order to better understand why either discrepancies or consensus might exist between buyers' and supplier's perceptions. We also recommended future work focus on understanding the development process of social capital in BSRs by understanding vital structural (e.g., distance between buyer and supplier) and relational (e. g., justice) antecedents as conduits to foster social capital. In addition, we advocated researchers to explore the interaction relationship among social capital dimensions using the CFM, which addresses the limitation of the conventional complementary and substitutive views of the inability to determine the specific dimension that should be improved to achieve the maximum outcome. Moreover, we encouraged more work to explore the risks of social capital, to understand the underlying mechanisms through which social capital might harm BSRs, and to investigate how any harmful impact might be minimised or eliminated through moderating variables. Furthermore, we called for more future research to adopt a contingency approach when investigating the outcomes of social capital in BSRs and to adopt a configuration approach in which more aspects of BSRs can simultaneously be accounted for.

\subsection{Limitations}

This review has a number of limitations which should be acknowledged. We considered only articles published in the CABS journals list to help ensure a rigorous and quality initial synthesis of the current research on social capital in BSRs. Future studies may wish to include articles published in other journals, conference papers, and books. Moreover, this review focused only on those studies that examined the core constructs of social capital, omitting those studies that applied social capital theory as an explanatory framework without examining its construct and different dimensions. Accordingly, a further interesting avenue for future research would be to evaluate the application and extension of social capital theory as an emerging theoretical lens in the BSR research and moreover, in the broader supply chain management literature. Furthermore, we reviewed social capital only in BSRs which represents only one type of inter-organizational relationships. This 
narrow scope and focus enabled us to provide an in-depth analysis (Webster \& Watson, 2002) and detailed discussion of the antecedents, benefits, risks, and boundary conditions of social capital. Extending the reach of our review within the inter-organizational relationship domain by replicating our study and analysing social capital in other types of inter-organizational relationships such as strategic alliances and joint ventures would be highly beneficial. Finally, although we have complemented our systematic search with snowballing search technique (backward and forward) to ensure that no relevant papers were omitted in our review, some papers may have been left out.

\section{Declaration of Competing Interest}

None.

This research did not receive any specific grant from funding agencies in the public, commercial, or not-for-profit sectors.

Appendix A. A summary of the selected papers

\begin{tabular}{|c|c|c|c|c|c|c|c|c|c|c|c|}
\hline \multirow[t]{2}{*}{ No } & \multirow[t]{2}{*}{ Author(s) } & \multicolumn{3}{|c|}{ Dimensions } & \multirow{2}{*}{$\begin{array}{l}\text { Research } \\
\text { theme } \\
\text { (Antecedents, } \\
\text { benefits, risks } \\
\text { and/or } \\
\text { boundary } \\
\text { conditions) }\end{array}$} & \multirow{2}{*}{$\begin{array}{l}\text { Type of Buyer- } \\
\text { supplier } \\
\text { relationship }\end{array}$} & \multirow[t]{2}{*}{ Perspective } & \multirow[t]{2}{*}{ Method } & \multicolumn{2}{|l|}{ Context } & \multirow[t]{2}{*}{ Relevant findings } \\
\hline & & $\mathrm{RC}$ & $\mathrm{CC}$ & SS & & & & & Industry & Country & \\
\hline 1 & $\begin{array}{l}\text { Erridge and } \\
\text { Greer }(2002)^{\mathrm{a}}\end{array}$ & & & & $\begin{array}{l}\text { - Benefits } \\
\text { - Risks }\end{array}$ & Buyer-supplier & Buyer & Case study & NS & UK & $\begin{array}{l}\text { Social capital } \\
\text { increases access to } \\
\text { resource and } \\
\text { information, reduce } \\
\text { transaction costs, } \\
\text { improve contract } \\
\text { specifications, } \\
\text { facilitating shared } \\
\text { risks, and improving } \\
\text { co-operative action. } \\
\text { However, it can } \\
\text { reduce competition, } \\
\text { restrict the flow of } \\
\text { information, and } \\
\text { increase } \\
\text { opportunism. }\end{array}$ \\
\hline 2 & $\begin{array}{l}\text { Chou et al. } \\
\text { (2006) }\end{array}$ & $\checkmark$ & $\checkmark$ & $\checkmark$ & $\begin{array}{l}\text { - Benefits } \\
\text { - Risks }\end{array}$ & Buyer-provider & Buyer & Case study & $\begin{array}{l}\text { Information } \\
\text { technology }\end{array}$ & Taiwan & $\begin{array}{l}\text { Although pre-social } \\
\text { capital facilities IT } \\
\text { outsourcing and } \\
\text { collaboration, it can } \\
\text { undermine the } \\
\text { rationality of } \\
\text { outsourcing decision } \\
\text { by reducing the } \\
\text { likelihood of } \\
\text { considering better } \\
\text { alternative providers. }\end{array}$ \\
\hline 3 & $\begin{array}{l}\text { Cousins et al. } \\
(2006)\end{array}$ & $\checkmark$ & & & $\begin{array}{l}\text { - Antecedents } \\
\text { - Benefits }\end{array}$ & Buyer-supplier & 111 buyers & Survey & $\begin{array}{l}\text { Multiple } \\
\text { Industries }\end{array}$ & UK & $\begin{array}{l}\text { Informal socialisation } \\
\text { leads to the } \\
\text { development of RC, } \\
\text { which in turn, } \\
\text { improves supplier } \\
\text { relationship } \\
\text { outcomes. Formal } \\
\text { socialisations } \\
\text { facilities informal } \\
\text { socialisation that } \\
\text { leads to the } \\
\text { development of RC. }\end{array}$ \\
\hline 4 & $\begin{array}{l}\text { Chang and } \\
\text { Gotcher (2007) }\end{array}$ & $\checkmark$ & & & - Benefits & Buyer-supplier & 118 suppliers & Survey & $\begin{array}{l}\text { Multiple } \\
\text { industries }\end{array}$ & Taiwan & $\begin{array}{l}\text { RC enhances supply } \\
\text { chain relationship } \\
\text { learning. RC } \\
\text { positively moderates } \\
\text { the relationship } \\
\text { between relationship- } \\
\text { specific investment } \\
\text { and relationship } \\
\text { learning. }\end{array}$ \\
\hline 5 & $\begin{array}{l}\text { Krause et al. } \\
\text { (2007) }\end{array}$ & $\checkmark$ & $\checkmark$ & $\checkmark$ & - Benefits & Buyer-supplier & 392 buyers & Survey & $\begin{array}{l}\text { Multiple } \\
\text { industries }\end{array}$ & US & $\begin{array}{l}\text { CC is positively } \\
\text { associated with both } \\
\text { buyer's cost } \\
\text { performance and } \\
\text { operational } \\
\text { performance. RC is } \\
\text { important in } \\
\text { achieving costs } \\
\text { (continued on next page) }\end{array}$ \\
\hline
\end{tabular}


(continued)

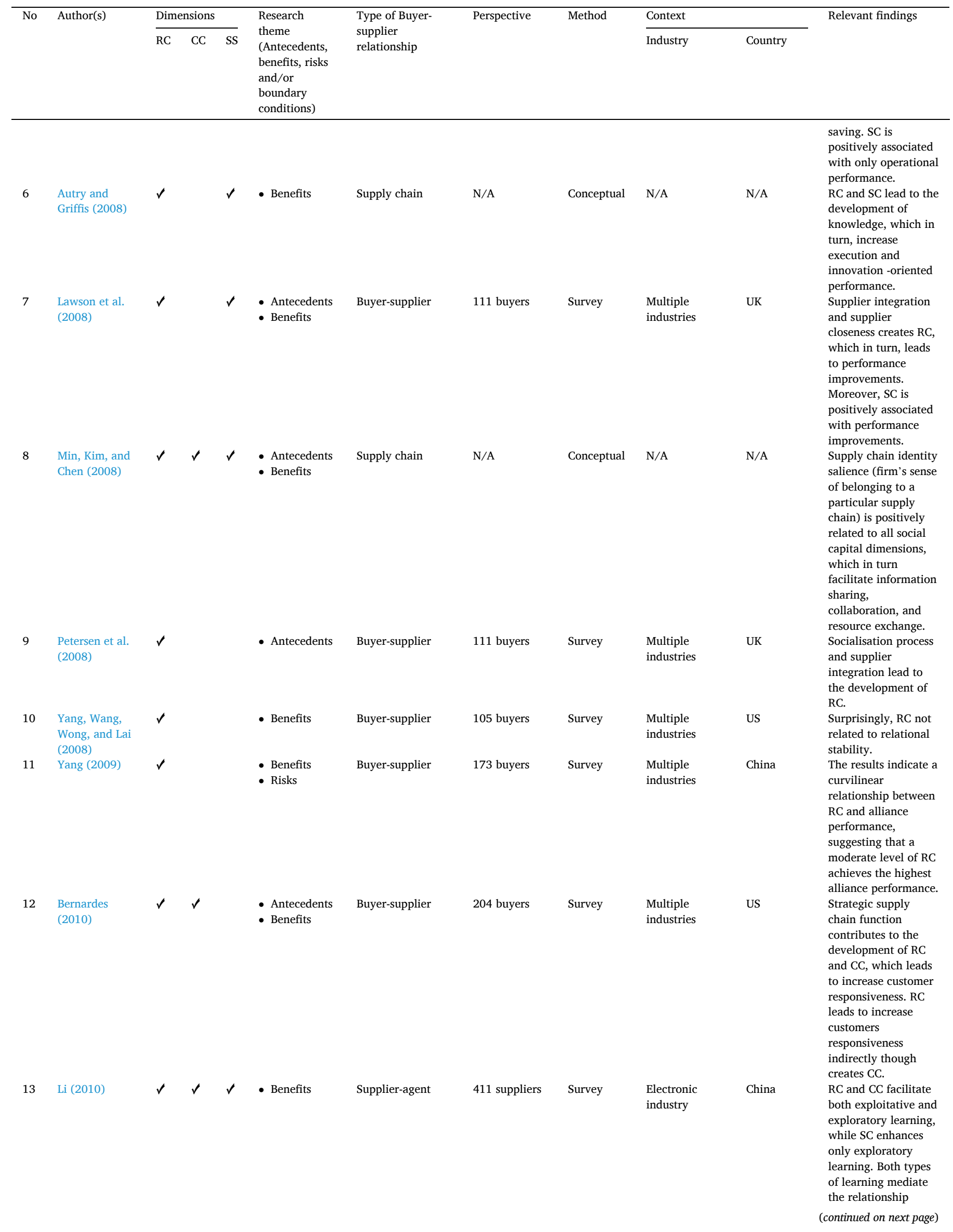


(continued)

\begin{tabular}{|c|c|c|c|c|c|c|c|c|c|c|c|}
\hline \multirow[t]{2}{*}{ No } & \multirow[t]{2}{*}{ Author(s) } & \multicolumn{3}{|c|}{ Dimensions } & \multirow{2}{*}{$\begin{array}{l}\text { Research } \\
\text { theme } \\
\text { (Antecedents, } \\
\text { benefits, risks } \\
\text { and/or } \\
\text { boundary } \\
\text { conditions) }\end{array}$} & \multirow{2}{*}{$\begin{array}{l}\text { Type of Buyer- } \\
\text { supplier } \\
\text { relationship }\end{array}$} & \multirow[t]{2}{*}{ Perspective } & \multirow[t]{2}{*}{ Method } & \multicolumn{2}{|l|}{ Context } & \multirow[t]{2}{*}{ Relevant findings } \\
\hline & & $\mathrm{RC}$ & CC & SS & & & & & Industry & Country & \\
\hline 14 & $\begin{array}{l}\text { Carey et al. } \\
\text { (2011) }\end{array}$ & $\checkmark$ & $\checkmark$ & $\checkmark$ & $\begin{array}{l}\text { - Benefits } \\
\text { - Boundary } \\
\text { conditions }\end{array}$ & Buyer-supplier & 163 buyers & Survey & $\begin{array}{l}\text { Multiple } \\
\text { industries }\end{array}$ & UK & $\begin{array}{l}\text { between social } \\
\text { capital and } \\
\text { relationship value. } \\
\text { CC and SC are } \\
\text { positively related to } \\
\text { the development of } \\
\text { RC, which in turn, } \\
\text { leads to cost and } \\
\text { innovation } \\
\text { improvements. Legal } \\
\text { bonds (as formal } \\
\text { governance) increase } \\
\text { the impact of RC on } \\
\text { both buyer } \\
\text { innovation and cost } \\
\text { improvements. }\end{array}$ \\
\hline 15 & $\begin{array}{l}\text { Carey and } \\
\text { Lawson } \\
(2011)^{\mathrm{a}}\end{array}$ & & & & $\begin{array}{l}\text { - Antecedents } \\
\text { - Boundary } \\
\text { conditions }\end{array}$ & Buyer-supplier & N/A & Conceptual & N/A & N/A & $\begin{array}{l}\text { Relational and } \\
\text { contractual } \\
\text { governance positively } \\
\text { related to the } \\
\text { development of social } \\
\text { capital. However, the } \\
\text { effect of contractual } \\
\text { governance is } \\
\text { stronger under higher } \\
\text { level of demand } \\
\text { uncertainty, while } \\
\text { the effect of relational } \\
\text { governance is } \\
\text { stronger under higher } \\
\text { level of supply } \\
\text { uncertainty. }\end{array}$ \\
\hline 16 & $\begin{array}{l}\text { Hammervoll } \\
\text { (2011) }\end{array}$ & $\checkmark$ & & & $\begin{array}{l}\text { - Antecedents } \\
\text { - Benefits }\end{array}$ & $\begin{array}{l}\text { Supply chain } \\
\text { relationships }\end{array}$ & N/A & Conceptual & N/A & N/A & $\begin{array}{l}\text { Socialisation } \\
\text { processes lead to the } \\
\text { development of RC, } \\
\text { which in turn, lead to } \\
\text { longer honeymoon } \\
\text { period (the time } \\
\text { period immediately } \\
\text { after SCR formation, } \\
\text { during which the } \\
\text { threat of dissolution } \\
\text { is non-existent). }\end{array}$ \\
\hline 17 & $\begin{array}{l}\text { Villena et al. } \\
\text { (2011) }\end{array}$ & $\checkmark$ & $\checkmark$ & $\checkmark$ & $\begin{array}{l}\text { - Benefits } \\
\text { - Risks }\end{array}$ & Buyer-supplier & 132 buyers & Survey & $\begin{array}{l}\text { Multiple } \\
\text { industries }\end{array}$ & Spain & $\begin{array}{l}\text { Social capital } \\
\text { dimensions are } \\
\text { positively related to } \\
\text { performance. A } \\
\text { curvilinear } \\
\text { relationship was } \\
\text { significant between } \\
\text { RC and both } \\
\text { operational and } \\
\text { strategic } \\
\text { performance, while } \\
\text { SC was only } \\
\text { significant for } \\
\text { operational } \\
\text { performance. }\end{array}$ \\
\hline 18 & $\begin{array}{l}\text { Chang, Cheng, } \\
\text { and } \mathrm{Wu}(2012)\end{array}$ & $\checkmark$ & & & - Benefits & Buyer-supplier & 104 buyers & Survey & $\begin{array}{l}\text { Multiple } \\
\text { industries }\end{array}$ & Taiwan & $\begin{array}{l}\text { Social capital (trust } \\
\text { and commitment) } \\
\text { facilitates innovation } \\
\text { and adaptation, } \\
\text { which in turn, leads } \\
\text { to improve } \\
\text { performance. }\end{array}$ \\
\hline 19 & $\begin{array}{l}\text { Grawe et al. } \\
\text { (2012) }\end{array}$ & $\checkmark$ & & & $\begin{array}{l}\text { - Antecedents } \\
\text { - Benefits }\end{array}$ & $\begin{array}{l}\text { Logistics provider- } \\
\text { customer }\end{array}$ & 81 dyads & Survey & $\begin{array}{l}\text { Multiple } \\
\text { industries }\end{array}$ & NS & $\begin{array}{l}\text { Organizational } \\
\text { implantation (on-site } \\
\text { representative) } \\
\text { enhances customers' } \\
\text { commitment towards } \\
\text { (continued on next page) }\end{array}$ \\
\hline
\end{tabular}


(continued)

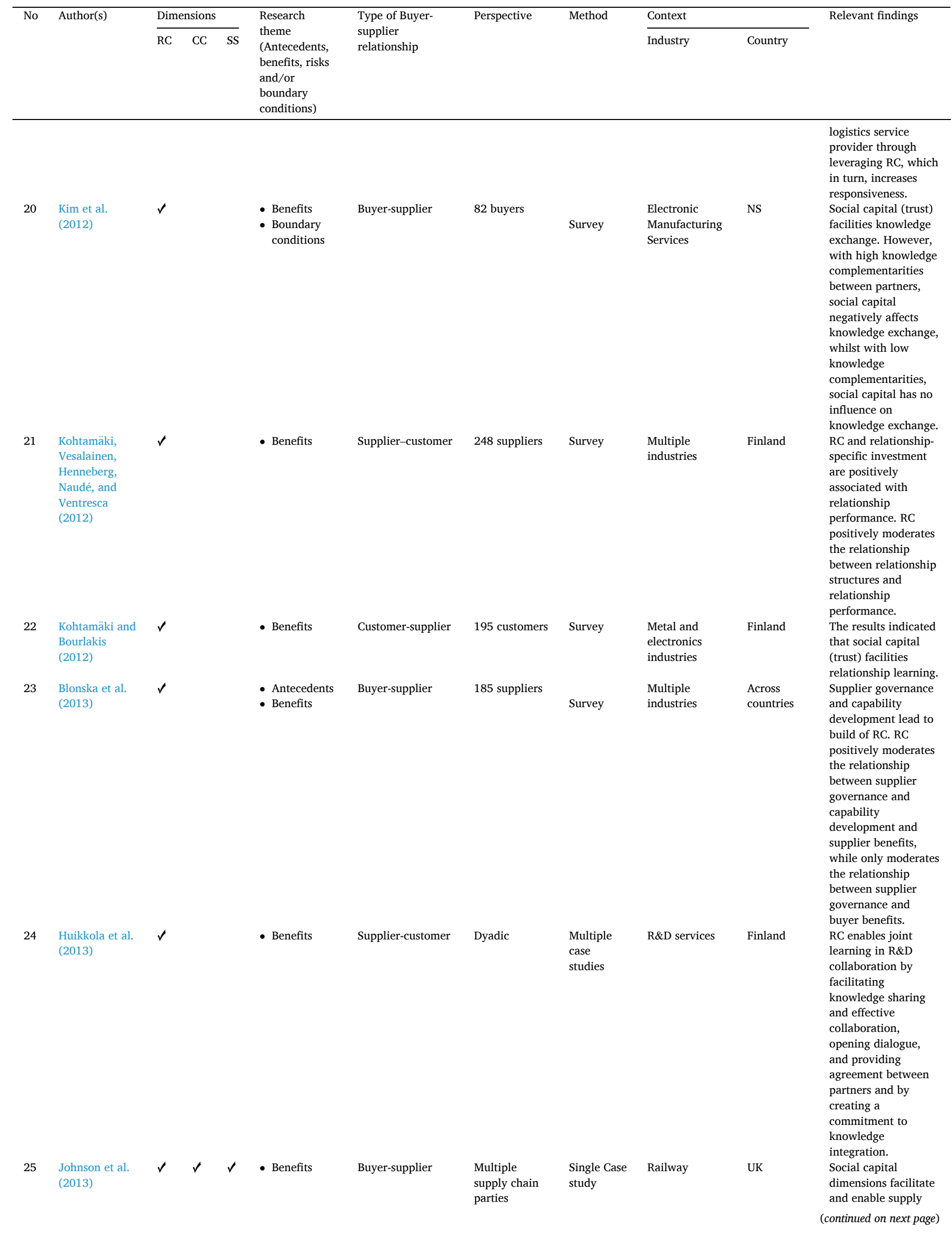


(continued)

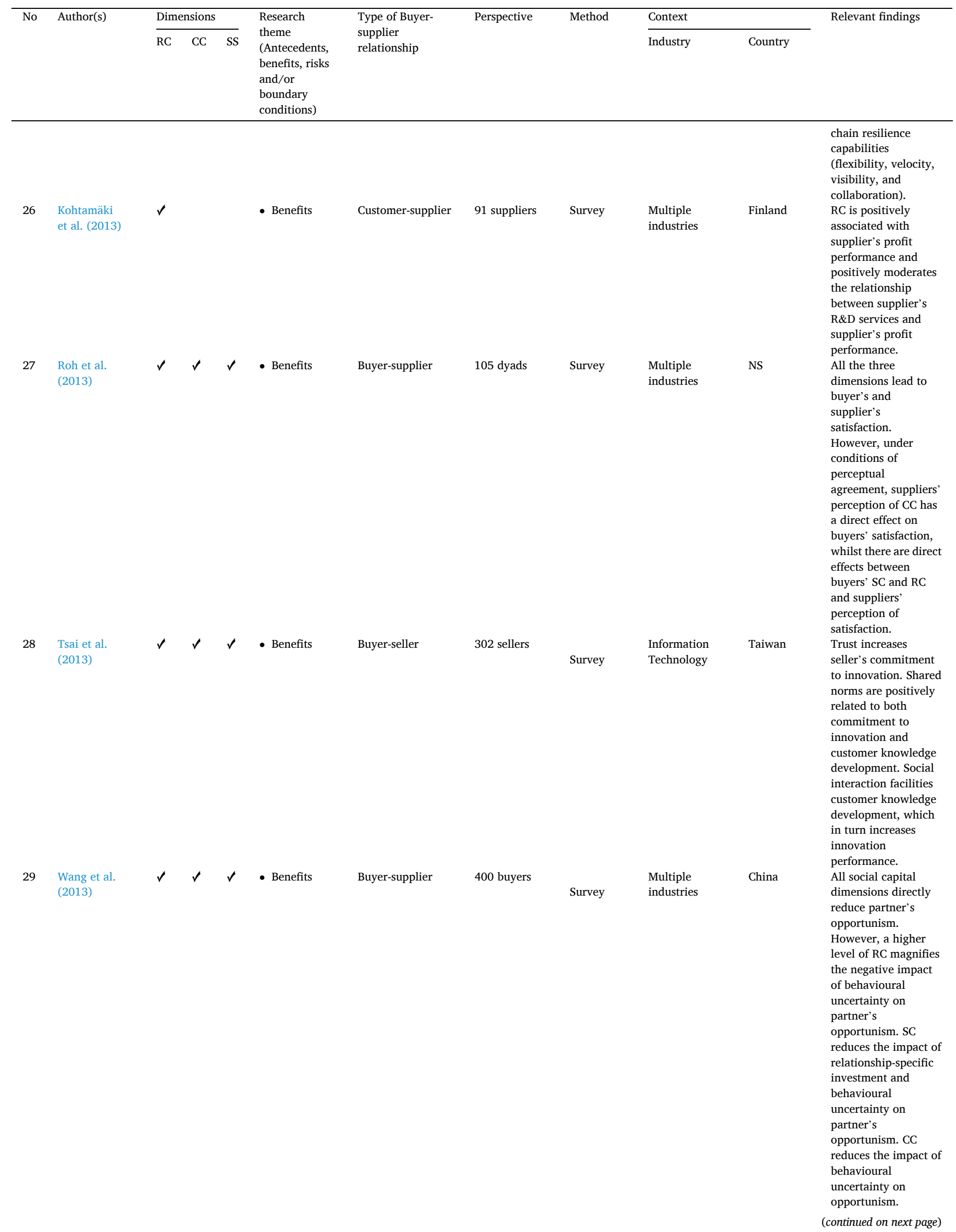


(continued)

\begin{tabular}{|c|c|c|c|c|c|c|c|c|c|c|c|}
\hline \multirow[t]{2}{*}{ No } & \multirow[t]{2}{*}{ Author(s) } & \multicolumn{3}{|c|}{ Dimensions } & \multirow[b]{2}{*}{$\begin{array}{l}\text { Research } \\
\text { theme } \\
\text { (Antecedents, } \\
\text { benefits, risks } \\
\text { and/or } \\
\text { boundary } \\
\text { conditions) }\end{array}$} & \multirow{2}{*}{$\begin{array}{l}\text { Type of Buyer- } \\
\text { supplier } \\
\text { relationship }\end{array}$} & \multirow[t]{2}{*}{ Perspective } & \multirow[t]{2}{*}{ Method } & \multicolumn{2}{|l|}{ Context } & \multirow[t]{2}{*}{ Relevant findings } \\
\hline & & RC & CC & SS & & & & & Industry & Country & \\
\hline 30 & $\begin{array}{l}\text { Yim and Leem } \\
\text { (2013) }\end{array}$ & $\checkmark$ & $\checkmark$ & $\checkmark$ & - Benefits & Buyer-supplier & 420 buyers & Survey & $\begin{array}{l}\text { Multiple } \\
\text { industries }\end{array}$ & South Korea & $\begin{array}{l}\text { All social capital } \\
\text { dimensions facilitate } \\
\text { supply chain } \\
\text { integration } \\
\text { (information sharing, } \\
\text { collaboration and } \\
\text { resource exchange), } \\
\text { which leads to } \\
\text { improve firm } \\
\text { performance. RC and } \\
\text { CC directly increase } \\
\text { firm performance. }\end{array}$ \\
\hline 31 & $\begin{array}{l}\text { Hartmann and } \\
\text { Herb (2014) }\end{array}$ & $\checkmark$ & $\checkmark$ & $\checkmark$ & - Benefits & Buyer-supplier & N/A & Conceptual & N/A & N/A & $\begin{array}{l}\text { Social capital } \\
\text { developed between } \\
\text { buyer and partner } \\
\text { (supplier) reduces } \\
\text { opportunistic } \\
\text { behaviour facing } \\
\text { buyer from the } \\
\text { service provider (the } \\
\text { third party) in a } \\
\text { service triad. }\end{array}$ \\
\hline 32 & $\begin{array}{l}\text { Horn et al. } \\
\text { (2014) }\end{array}$ & $\checkmark$ & $\checkmark$ & $\checkmark$ & $\begin{array}{l}\text { - Antecedents } \\
\text { - Benefits }\end{array}$ & Buyer-supplier & 82 buyers & Survey & $\begin{array}{l}\text { Automotive } \\
\text { industry }\end{array}$ & Germany & $\begin{array}{l}\text { Internal integration } \\
\text { (cross-functional) is } \\
\text { positively related to } \\
\text { the development of } \\
\text { CC and SC, which in } \\
\text { turn they lead to the } \\
\text { development of RC. } \\
\text { RC positively } \\
\text { influences external } \\
\text { integration. }\end{array}$ \\
\hline 33 & $\begin{array}{l}\text { Hung et al. } \\
\text { (2014) }\end{array}$ & $\checkmark$ & $\checkmark$ & $\checkmark$ & - Benefits & Buyer-supplier & 160 buyers & Survey & $\begin{array}{l}\text { Multiple } \\
\text { industries }\end{array}$ & Taiwan & $\begin{array}{l}\text { CC facilitates both } \\
\text { knowledge inflow } \\
\text { and outflow of green } \\
\text { supply chain, while } \\
\text { SC enables only } \\
\text { knowledge inflow, } \\
\text { which in turn, leads } \\
\text { to improve green } \\
\text { management } \\
\text { performance. RC has } \\
\text { no effect on both } \\
\text { knowledge inflow } \\
\text { and outflow. }\end{array}$ \\
\hline 34 & Li et al. (2014) & $\checkmark$ & $\checkmark$ & $\checkmark$ & - Benefits & Buyer-supplier & 272 buyers & Survey & $\begin{array}{l}\text { Multiple } \\
\text { industries }\end{array}$ & China & $\begin{array}{l}\text { Only RC and CC } \\
\text { improve the } \\
\text { information sharing } \\
\text { in term of content and } \\
\text { quality, which in turn } \\
\text { leads to improves } \\
\text { both efficiency and } \\
\text { responsiveness } \\
\text { performance. SC } \\
\text { facilities information } \\
\text { sharing indirectly } \\
\text { through developing } \\
\text { RC and CC. }\end{array}$ \\
\hline 35 & $\begin{array}{l}\text { Roden and } \\
\text { Lawson (2014) }\end{array}$ & $\checkmark$ & $\checkmark$ & $\checkmark$ & $\begin{array}{l}\text { - Antecedents } \\
\text { - Boundary } \\
\text { conditions }\end{array}$ & Buyer-supplier & 163 buyers & Survey & $\begin{array}{l}\text { Multiple } \\
\text { industries }\end{array}$ & UK & $\begin{array}{l}\text { CC and SC positively } \\
\text { impact RC. However, } \\
\text { CC negatively impact } \\
\text { RC and the positive } \\
\text { impact of SC is } \\
\text { stronger under high } \\
\text { level of buyer and } \\
\text { supplier adaptations. }\end{array}$ \\
\hline 36 & $\begin{array}{l}\text { Tseng and } \\
\text { Chen (2014) }\end{array}$ & $\checkmark$ & & & $\begin{array}{l}\text { - Benefits } \\
\text { - Boundary } \\
\text { conditions }\end{array}$ & Buyer-supplier & 84 buyers & Survey & $\begin{array}{l}\text { Multiple } \\
\text { industries }\end{array}$ & $\begin{array}{l}\text { Across } \\
\text { countries }\end{array}$ & $\begin{array}{l}\mathrm{RC} \text { is positively } \\
\text { related to the } \\
\text { development of } \\
\text { buyer's technological } \\
\text { (continued on next page) }\end{array}$ \\
\hline
\end{tabular}


(continued)

\begin{tabular}{|c|c|c|c|c|c|c|c|c|c|c|c|}
\hline \multirow[t]{2}{*}{ No } & \multirow[t]{2}{*}{ Author(s) } & \multicolumn{3}{|c|}{ Dimensions } & \multirow{2}{*}{$\begin{array}{l}\text { Research } \\
\text { theme } \\
\text { (Antecedents, } \\
\text { benefits, risks } \\
\text { and/or } \\
\text { boundary } \\
\text { conditions) }\end{array}$} & \multirow{2}{*}{$\begin{array}{l}\text { Type of Buyer- } \\
\text { supplier } \\
\text { relationship }\end{array}$} & \multirow[t]{2}{*}{ Perspective } & \multirow[t]{2}{*}{ Method } & \multicolumn{2}{|l|}{ Context } & \multirow[t]{2}{*}{ Relevant findings } \\
\hline & & $\mathrm{RC}$ & $\mathrm{CC}$ & SS & & & & & Industry & Country & \\
\hline 37 & $\begin{array}{l}\text { Unal and } \\
\text { Donthu (2014) }\end{array}$ & & $\checkmark$ & & - Benefits & Buyer-supplier & 60 dyads & Survey & $\begin{array}{l}\text { Consumer } \\
\text { packaged } \\
\text { goods }\end{array}$ & NS & $\begin{array}{l}\text { capability. Moreover, } \\
\text { as the buyer's } \\
\text { international } \\
\text { experience increases, } \\
\text { the impact of RC on } \\
\text { buyer's technological } \\
\text { capability increases. } \\
\text { RC is positively } \\
\text { related to the } \\
\text { development of } \\
\text { absorptive } \\
\text { capabilities, which in } \\
\text { turn positively } \\
\text { influences } \\
\text { performance. }\end{array}$ \\
\hline 38 & Lee (2015) & $\checkmark$ & & $\checkmark$ & $\begin{array}{l}\text { - Antecedents } \\
\text { - Benefits }\end{array}$ & Buyer-supplier & 248 suppliers & Survey & $\begin{array}{l}\text { Multiple } \\
\text { industries }\end{array}$ & South Korea & $\begin{array}{l}\text { Green supply chain } \\
\text { management } \\
\text { practices create RC } \\
\text { and SC, which in turn } \\
\text { improves supplier's } \\
\text { operational and } \\
\text { environmental } \\
\text { performance. }\end{array}$ \\
\hline 39 & $\begin{array}{l}\text { Lioliou and } \\
\text { Zimmermann } \\
(2015)\end{array}$ & $\checkmark$ & $\checkmark$ & $\checkmark$ & - Benefits & Buyer-supplier & Dyadic & $\begin{array}{l}\text { Multiple } \\
\text { case } \\
\text { studies }\end{array}$ & $\begin{array}{l}\text { Financial } \\
\text { service } \\
\text { industry }\end{array}$ & $\begin{array}{l}\text { Across } \\
\text { countries }\end{array}$ & $\begin{array}{l}\text { RC reduces } \\
\text { opportunism through } \\
\text { reducing behaviour } \\
\text { uncertainty between } \\
\text { partners. CC reduces } \\
\text { opportunism through } \\
\text { reducing internal } \\
\text { uncertainties. } \\
\text { Structural capital, } \\
\text { however, has no } \\
\text { direct impact but } \\
\text { helps in building both } \\
\text { relational and } \\
\text { cognitive. }\end{array}$ \\
\hline 40 & $\begin{array}{l}\text { Schiele, Ellis, } \\
\text { Eßig, Henke, } \\
\text { and Kull } \\
\text { (2015) }\end{array}$ & $\checkmark$ & $\checkmark$ & $\checkmark$ & - Benefits & Buyer-supplier & $\mathrm{N} / \mathrm{A}$ & Conceptual & $\mathrm{N} / \mathrm{A}$ & N/A & $\begin{array}{l}\text { Higher level of social } \\
\text { capital dimesons is } \\
\text { associated with high } \\
\text { level of supplier's } \\
\text { satisfaction, which in } \\
\text { turn, increases } \\
\text { supplier' motivation } \\
\text { to allocate resources } \\
\text { to the relationship. }\end{array}$ \\
\hline 41 & $\begin{array}{l}\text { Whipple, } \\
\text { Wiedmer, and } \\
\text { Boyer }(2015)^{\mathrm{a}}\end{array}$ & & & & $\begin{array}{l}\text { - Antecedents } \\
\text { - Benefits }\end{array}$ & Buyer-supplier & 105 dyads & Survey & $\begin{array}{l}\text { Multiple } \\
\text { industries }\end{array}$ & US & $\begin{array}{l}\text { Internal process } \\
\text { collaborative } \\
\text { competencies } \\
\text { facilities the } \\
\text { development of social } \\
\text { capital, which in turn } \\
\text { improves operational } \\
\text { performance. }\end{array}$ \\
\hline 42 & $\begin{array}{l}\text { Gelderman } \\
\text { et al. (2016) }\end{array}$ & $\checkmark$ & $\checkmark$ & $\checkmark$ & $\begin{array}{l}\text { - Benefits } \\
\text { - Boundary } \\
\text { conditions }\end{array}$ & Buyer-supplier & 88 suppliers & Survey & $\begin{array}{l}\text { Multiple } \\
\text { industries }\end{array}$ & $\begin{array}{l}\text { Across } \\
\text { countries }\end{array}$ & $\begin{array}{l}\text { Only CC is positively } \\
\text { associated with } \\
\text { supplier's strategic } \\
\text { performance. No } \\
\text { moderating effect of } \\
\text { technological } \\
\text { uncertainty. }\end{array}$ \\
\hline 43 & $\begin{array}{l}\text { Jia, } \\
\text { Rutherford, } \\
\text { and Lamming } \\
\text { (2016) }\end{array}$ & $\checkmark$ & & & $\begin{array}{l}\text { - Antecedents } \\
\text { - Benefits }\end{array}$ & Buyer-supplier & Dyadic & $\begin{array}{l}\text { Multiple } \\
\text { case } \\
\text { studies }\end{array}$ & $\begin{array}{l}\text { Multiple } \\
\text { industries }\end{array}$ & $\begin{array}{l}\text { Across } \\
\text { countries }\end{array}$ & $\begin{array}{l}\text { Buyer-supplier } \\
\text { informal and formal } \\
\text { socialisation process } \\
\text { lead to culture } \\
\text { adaptation, which } \\
\text { creates a hybrid } \\
\text { culture that develop } \\
\text { RC. RC facilitates } \\
\text { (continued on next page) }\end{array}$ \\
\hline
\end{tabular}


(continued)

\begin{tabular}{|c|c|c|c|c|c|c|c|c|c|c|c|}
\hline \multirow[t]{2}{*}{ No } & \multirow[t]{2}{*}{ Author(s) } & \multicolumn{3}{|c|}{ Dimensions } & \multirow{2}{*}{$\begin{array}{l}\text { Research } \\
\text { theme } \\
\text { (Antecedents, } \\
\text { benefits, risks } \\
\text { and/or } \\
\text { boundary } \\
\text { conditions) }\end{array}$} & \multirow{2}{*}{$\begin{array}{l}\text { Type of Buyer- } \\
\text { supplier } \\
\text { relationship }\end{array}$} & \multirow[t]{2}{*}{ Perspective } & \multirow[t]{2}{*}{ Method } & \multicolumn{2}{|l|}{ Context } & \multirow[t]{2}{*}{ Relevant findings } \\
\hline & & $\mathrm{RC}$ & $\mathrm{CC}$ & SS & & & & & Industry & Country & \\
\hline & & & & & & & & & & & $\begin{array}{l}\text { deep socialisation } \\
\text { process. }\end{array}$ \\
\hline 44 & $\begin{array}{l}\text { Kulangara } \\
\text { et al. (2016) }\end{array}$ & $\checkmark$ & & $\checkmark$ & - Benefits & Buyer-supplier & 357 buyers & Survey & $\begin{array}{l}\text { Multiple } \\
\text { industries }\end{array}$ & US & $\begin{array}{l}\text { RC and SC have a } \\
\text { positive impact on } \\
\text { buyer's innovation } \\
\text { capability. SC } \\
\text { enhances innovation } \\
\text { capability indirectly } \\
\text { through increasing } \\
\text { trust. }\end{array}$ \\
\hline 45 & $\begin{array}{l}\text { Miocevic } \\
\text { (2016) }\end{array}$ & $\checkmark$ & & & $\begin{array}{l}\text { - Antecedents } \\
\text { - Boundary } \\
\text { conditions }\end{array}$ & Buyer-seller & 122 sellers & Survey & $\begin{array}{l}\text { Multiple } \\
\text { industries }\end{array}$ & Croatia & $\begin{array}{l}\text { Buyer's reliance and } \\
\text { relational bonding } \\
\text { norms enhance RC. } \\
\text { As formal } \\
\text { institutional distance } \\
\text { decreases, the } \\
\text { positive impact of } \\
\text { buyer's reliance on } \\
\text { RC is stronger. As } \\
\text { informal institutional } \\
\text { distance deceases, the } \\
\text { positive impact of } \\
\text { relational bonding } \\
\text { norms on RC is } \\
\text { stronger. }\end{array}$ \\
\hline 46 & $\begin{array}{l}\text { Presutti et al. } \\
(2016)\end{array}$ & $\checkmark$ & $\checkmark$ & $\checkmark$ & $\begin{array}{l}\text { - Benefits } \\
\text { - Boundary } \\
\text { conditions }\end{array}$ & Supplier-customer & 101 suppliers & Survey & Electronics & Italy & $\begin{array}{l}\text { Social capital } \\
\text { dimensions positively } \\
\text { related to supplier's } \\
\text { foreign economic } \\
\text { performance. } \\
\text { However, with low } \\
\text { levels of psychic } \\
\text { distance the positive } \\
\text { impact of RC and CC } \\
\text { increases. The } \\
\text { positive impact of all } \\
\text { dimensions is only for } \\
\text { high geographical } \\
\text { distance between the } \\
\text { partners. }\end{array}$ \\
\hline 47 & $\begin{array}{l}\text { Son et al. } \\
(2016)\end{array}$ & $\checkmark$ & $\checkmark$ & $\checkmark$ & $\begin{array}{l}\text { - Benefits } \\
\text { - Risks }\end{array}$ & Retailer-supplier & $\begin{array}{l}\text { Dyadic (12 } \\
\text { retailers and } \\
70 \text { suppliers) }\end{array}$ & Survey & $\begin{array}{l}\text { Fast-moving } \\
\text { consumer } \\
\text { goods }\end{array}$ & Korea & $\begin{array}{l}\text { Three social capital } \\
\text { configurations with a } \\
\text { varied level of RC, CC } \\
\text { and SC. Higher level } \\
\text { of social capital } \\
\text { increases both } \\
\text { strategic and } \\
\text { operational } \\
\text { performance to a } \\
\text { certain level, } \\
\text { suggesting a } \\
\text { curvilinear } \\
\text { relationship. High } \\
\text { dissonance in the } \\
\text { level of CC is } \\
\text { associated with lower } \\
\text { level of strategic and } \\
\text { operational } \\
\text { performance }\end{array}$ \\
\hline 48 & $\begin{array}{l}\text { Cho et al. } \\
\text { (2017) }\end{array}$ & $\checkmark$ & $\checkmark$ & $\checkmark$ & - Benefits & Buyer-supplier & 317 buyers & Survey & Restaurant & USA & $\begin{array}{l}\text { Social capital } \\
\text { dimensions positively } \\
\text { influence product } \\
\text { enhancement. } \\
\text { However, excessive } \\
\text { level of RC negatively } \\
\text { affects product } \\
\text { enhancement. RC and } \\
\text { CC positively } \\
\text { influence new } \\
\text { product development } \\
\text { (continued on next page) }\end{array}$ \\
\hline
\end{tabular}


(continued)

\begin{tabular}{|c|c|c|c|c|c|c|c|c|c|c|}
\hline \multirow[t]{2}{*}{ No } & \multirow[t]{2}{*}{ Author(s) } & \multicolumn{3}{|c|}{ Dimensions } & \multirow{2}{*}{$\begin{array}{l}\text { Research } \\
\text { theme } \\
\text { (Antecedents, } \\
\text { benefits, risks } \\
\text { and/or } \\
\text { boundary } \\
\text { conditions) }\end{array}$} & \multirow{2}{*}{$\begin{array}{l}\text { Type of Buyer- } \\
\text { supplier } \\
\text { relationship }\end{array}$} & \multirow[t]{2}{*}{ Perspective } & \multirow[t]{2}{*}{ Method } & \multicolumn{2}{|l|}{ Context } \\
\hline & & $\mathrm{RC}$ & CC & SS & & & & & Industry & Country \\
\hline
\end{tabular}

49

Nabi et al. (2017)

50 Kim et al. (2017)

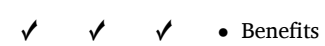

$51 \quad$ Leem and
Rogers (2017)

52

Jean, Kim, and

Bello (2017)

53 Preston et al. (2017)

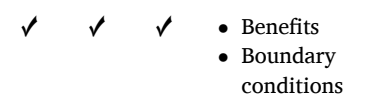

Boundary
conditions

Multiple supply

chain partners

420 multiple

supply chain

partners

Survey

NS

Multiple

industries

- Benefits

$\checkmark$

.
204 suppliers

204 suppliers

Survey

Electronic

Taiwan

Buyer-supplier

- Boundary

conditions
54 Verwaal

(2017)

55 Villena and

Craighead

(2017)
- Benefits

- Boundary

conditions
Manufacturer-

supplier

223

manufacturers

Survey

Multiple

industries

Buyer-supplier

106 dyads

Survey
Multiple industries
South Korea

to a certain level then become negatively related to new product development.

RC and SC lead to

improved buyersupplier relationship performance in terms of quality, cost and delivery. CC improves performance through leveraging RC.

Fairness and referent power positively influence RC and SC, which in turn improve supplier's innovation performance.

Social capital

dimensions positively influence

performance.

However, this influence varies according to the supply chain role. For the supplier and distributor, only RC and CC positively influence

performance. For the manufacturer and logistics provider, all the three dimensions positively impact firm performance.

RC capital creates proactive customer orientation and facilitates joint learning, which in turn increase innovation.

SC and CC influence RC. RC increases the transfer of knowledge from the buyer to the supplier, which in turn, leads to greater supplier cost efficiency and innovation. However, this influence decreases in lengthier buyer-supplier relationships.

Netherlands Supplier RC mitigates and at high levels may even neutralize the negative effect of global outsourcing on firm financial performance. $\mathrm{RC}$ reduces opportunism only when both buyer and supplier share the same levels of RC. (continued on next page) 
(continued)

\begin{tabular}{|c|c|c|c|c|c|c|c|c|c|c|c|}
\hline \multirow[t]{2}{*}{ No } & \multirow[t]{2}{*}{ Author(s) } & \multicolumn{3}{|c|}{ Dimensions } & \multirow{2}{*}{$\begin{array}{l}\text { Research } \\
\text { theme } \\
\text { (Antecedents, } \\
\text { benefits, risks } \\
\text { and/or } \\
\text { boundary } \\
\text { conditions) }\end{array}$} & \multirow{2}{*}{$\begin{array}{l}\text { Type of Buyer- } \\
\text { supplier } \\
\text { relationship }\end{array}$} & \multirow[t]{2}{*}{ Perspective } & \multirow[t]{2}{*}{ Method } & \multicolumn{2}{|l|}{ Context } & \multirow[t]{2}{*}{ Relevant findings } \\
\hline & & $\mathrm{RC}$ & CC & SS & & & & & Industry & Country & \\
\hline 56 & $\begin{array}{l}\text { Wang and Li } \\
\text { (2017) }\end{array}$ & $\checkmark$ & $\checkmark$ & $\checkmark$ & - Benefits & Buyer-supplier & 297 Suppliers & Survey & $\begin{array}{l}\text { Multiple } \\
\text { industries }\end{array}$ & China & $\begin{array}{l}\text { The party with a } \\
\text { higher level of RC } \\
\text { than its counterpart } \\
\text { perceived to be more } \\
\text { opportunist. Buyers } \\
\text { observe reduced } \\
\text { benefits and suppliers } \\
\text { perceive slightly } \\
\text { improved benefits } \\
\text { when suppliers have } \\
\text { higher levels of RC. } \\
\text { RC is positively } \\
\text { related to the } \\
\text { development of both } \\
\text { supplier's potential } \\
\text { absorptive capacity } \\
\text { (PAC) and realised } \\
\text { absorptive capacity } \\
\text { (RAC), while SC is } \\
\text { only positively } \\
\text { related to the } \\
\text { development of } \\
\text { supplier's PAC. }\end{array}$ \\
\hline 57 & $\begin{array}{l}\text { Wang et al. } \\
\text { (2017) }\end{array}$ & $\checkmark$ & $\checkmark$ & $\checkmark$ & $\begin{array}{l}\text { - Benefits } \\
\text { - Risks } \\
\text { - Boundary } \\
\text { conditions }\end{array}$ & Buyer-supplier & 200 suppliers & Survey & $\begin{array}{l}\text { Multiple } \\
\text { industries }\end{array}$ & China & $\begin{array}{l}\text { RC and SC positively } \\
\text { affect exploitative } \\
\text { learning, while } \\
\text { negatively affect } \\
\text { exploratory learning. } \\
\text { However, with } \\
\text { contract specificity, } \\
\text { the positive impact of } \\
\text { RC and SC on } \\
\text { exploitative learning } \\
\text { is stronger, while the } \\
\text { negative impact of RC } \\
\text { and SC on exploratory } \\
\text { learning is stronger. }\end{array}$ \\
\hline 58 & $\begin{array}{l}\text { Wiengarten, } \\
\text { Singh, Fynes, } \\
\text { and Nazarpour } \\
\text { (2017) }\end{array}$ & $\checkmark$ & $\checkmark$ & $\checkmark$ & - Benefits & $\begin{array}{l}\text { Buyer-supply } \\
\text { chain partners }\end{array}$ & 更 & Survey & $\begin{array}{l}\text { Multiple } \\
\text { industries }\end{array}$ & $\begin{array}{l}\text { Across } \\
\text { countries }\end{array}$ & $\begin{array}{l}\text { While RC positively } \\
\text { moderates the } \\
\text { relationship between } \\
\text { mass customization } \\
\text { (MS) and cost and } \\
\text { flexibility } \\
\text { performance, CC only } \\
\text { positively moderates } \\
\text { the relationship } \\
\text { between MS and cost } \\
\text { performance. No } \\
\text { moderating effect } \\
\text { was found for } \\
\text { structural capital. }\end{array}$ \\
\hline 59 & $\begin{array}{l}\text { Zhang et al. } \\
(2017)^{\mathrm{a}}\end{array}$ & & & & $\begin{array}{l}\text { - Benefits } \\
\text { - Boundary } \\
\text { conditions }\end{array}$ & Buyer-supplier & 276 buyers & Survey & $\begin{array}{l}\text { Multiple } \\
\text { industries }\end{array}$ & China & $\begin{array}{l}\text { Social capital } \\
\text { positively associated } \\
\text { with knowledge } \\
\text { acquisition, } \\
\text { knowledge } \\
\text { combination, and } \\
\text { operational } \\
\text { performance. For } \\
\text { servitiased firms, } \\
\text { social capital directly } \\
\text { and indirectly } \\
\text { (through knowledge } \\
\text { combination) } \\
\text { enhances operational } \\
\text { performance. In the } \\
\text { traditional } \\
\text { manufacturing firms, } \\
\text { social capital } \\
\text { indirectly improves } \\
\text { (continued on next page) }\end{array}$ \\
\hline
\end{tabular}


(continued)

\begin{tabular}{|c|c|c|c|c|c|c|c|c|c|c|c|}
\hline \multirow[t]{2}{*}{ No } & \multirow[t]{2}{*}{ Author(s) } & \multicolumn{3}{|c|}{ Dimensions } & \multirow{2}{*}{$\begin{array}{l}\text { Research } \\
\text { theme } \\
\text { (Antecedents, } \\
\text { benefits, risks } \\
\text { and/or } \\
\text { boundary } \\
\text { conditions) }\end{array}$} & \multirow{2}{*}{$\begin{array}{l}\text { Type of Buyer- } \\
\text { supplier } \\
\text { relationship }\end{array}$} & \multirow[t]{2}{*}{ Perspective } & \multirow[t]{2}{*}{ Method } & \multicolumn{2}{|l|}{ Context } & \multirow[t]{2}{*}{ Relevant findings } \\
\hline & & RC & CC & SS & & & & & Industry & Country & \\
\hline 60 & $\begin{array}{l}\text { Fan and } \\
\text { Stevenson } \\
(2018)\end{array}$ & $\checkmark$ & $\checkmark$ & $\checkmark$ & $\begin{array}{l}\text { - Benefits } \\
\text { - Boundary } \\
\text { conditions }\end{array}$ & Buyers-supplier & Ten buyers & $\begin{array}{l}\text { Multiple- } \\
\text { case study }\end{array}$ & $\begin{array}{l}\text { Multiple } \\
\text { industries }\end{array}$ & China & $\begin{array}{l}\text { operational } \\
\text { performance through } \\
\text { facilitating } \\
\text { knowledge } \\
\text { acquisition. } \\
\text { All organizational } \\
\text { social capital } \\
\text { dimensions facilitate } \\
\text { the identification of } \\
\text { supply chain risk. } \\
\text { However, when } \\
\text { individual social } \\
\text { capital is used for } \\
\text { individual's own } \\
\text { interest (vs } \\
\text { organization's), the } \\
\text { impact of } \\
\text { organizational social } \\
\text { capital on risk } \\
\text { identification is } \\
\text { undermined. }\end{array}$ \\
\hline 61 & $\begin{array}{l}\text { Handoko et al. } \\
\text { (2018) }\end{array}$ & $\checkmark$ & $\checkmark$ & $\checkmark$ & $\begin{array}{l}\text { - Benefits } \\
\text { - Risks } \\
\text { - Boundary } \\
\text { conditions }\end{array}$ & Buyer-supplier & Suppliers & Case study & $\begin{array}{l}\text { Automotive } \\
\text { industry }\end{array}$ & Indonesia & $\begin{array}{l}\text { Social capital has } \\
\text { both enhancing and } \\
\text { inhabiting effect on } \\
\text { knowledge exchange } \\
\text { between buyer- } \\
\text { supplier. However, } \\
\text { this depending on } \\
\text { governance mode, } \\
\text { power-dependence, } \\
\text { and internal } \\
\text { conditions. }\end{array}$ \\
\hline 62 & $\begin{array}{l}\text { Lee and Ha } \\
\text { (2018) }\end{array}$ & $\checkmark$ & $\checkmark$ & $\checkmark$ & - Benefits & Buyer-supplier & 210 buyers & Survey & $\begin{array}{l}\text { Multiple } \\
\text { industries }\end{array}$ & Korea & $\begin{array}{l}\text { All social capital } \\
\text { dimensions increase } \\
\text { information inflow } \\
\text { from suppliers. } \\
\text { However, only RC } \\
\text { increases information } \\
\text { outflow from buyers } \\
\text { to suppliers. }\end{array}$ \\
\hline 63 & $\begin{array}{l}\text { Qian et al. } \\
\text { (2018) }\end{array}$ & $\checkmark$ & $\checkmark$ & $\checkmark$ & $\begin{array}{l}\text { - Benefits } \\
\text { - Boundary } \\
\text { conditions }\end{array}$ & $\begin{array}{l}\text { Supplier- } \\
\text { distributor }\end{array}$ & $\begin{array}{l}393 \\
\text { distributors }\end{array}$ & Survey & $\begin{array}{l}\text { Computer } \\
\text { industry }\end{array}$ & China & $\begin{array}{l}\text { SC positively } \\
\text { influences buyer's } \\
\text { performance. } \\
\text { However, under a } \\
\text { higher level of RC and } \\
\text { political ties and a } \\
\text { moderate level of } \\
\text { business ties, the } \\
\text { positive impact of SC } \\
\text { on buyer's } \\
\text { performance is } \\
\text { stronger. }\end{array}$ \\
\hline 64 & $\begin{array}{l}\text { Shou et al. } \\
\text { (2018) }\end{array}$ & $\checkmark$ & & $\checkmark$ & $\begin{array}{l}\text { - Antecedents } \\
\text { - Benefits }\end{array}$ & Buyer-supplier & $\begin{array}{l}389 \text { focal } \\
\text { company }\end{array}$ & Survey & NS & $\begin{array}{l}\text { Multiple } \\
\text { countries }\end{array}$ & $\begin{array}{l}\text { Human capital and } \\
\text { SC positively } \\
\text { influence RC. RC, but } \\
\text { not SC, increases } \\
\text { supplier intelligence } \\
\text { integration. }\end{array}$ \\
\hline 65 & $\begin{array}{l}\text { Sukoco et al. } \\
\text { (2018) }\end{array}$ & $\checkmark$ & $\checkmark$ & $\checkmark$ & - Benefits & Buyer-supplier & 211 suppliers & Survey & $\begin{array}{l}\text { Automotive } \\
\text { industry }\end{array}$ & Indonesia & $\begin{array}{l}\text { SC and CC capital } \\
\text { lead to RC. RC } \\
\text { positively related to } \\
\text { joint sensemaking but } \\
\text { not related to } \\
\text { knowledge sharing } \\
\text { and knowledge } \\
\text { integration. }\end{array}$ \\
\hline 66 & $\begin{array}{l}\text { Tipu and } \\
\text { Fantazy } \\
(2018)^{\mathrm{a}}\end{array}$ & & & & - Benefits & Buyer-supplier & 242 buyers & Survey & $\begin{array}{l}\text { Multiple } \\
\text { industries }\end{array}$ & Pakistan & $\begin{array}{l}\text { Social capital } \\
\text { positively influences } \\
\text { the implementation } \\
\text { of sustainable supply }\end{array}$ \\
\hline & & & & & & & & & & & (continued on next page) \\
\hline
\end{tabular}


(continued)

\begin{tabular}{|c|c|c|c|c|c|c|c|c|c|c|c|}
\hline \multirow[t]{2}{*}{ No } & \multirow[t]{2}{*}{ Author(s) } & \multicolumn{3}{|c|}{ Dimensions } & \multirow{2}{*}{$\begin{array}{l}\text { Research } \\
\text { theme } \\
\text { (Antecedents, } \\
\text { benefits, risks } \\
\text { and/or } \\
\text { boundary } \\
\text { conditions) }\end{array}$} & \multirow{2}{*}{$\begin{array}{l}\text { Type of Buyer- } \\
\text { supplier } \\
\text { relationship }\end{array}$} & \multirow[t]{2}{*}{ Perspective } & \multirow[t]{2}{*}{ Method } & \multicolumn{2}{|l|}{ Context } & \multirow[t]{2}{*}{ Relevant findings } \\
\hline & & $\mathrm{RC}$ & $\mathrm{CC}$ & SS & & & & & Industry & Country & \\
\hline 67 & $\begin{array}{l}\text { Uzunca } \\
(2018)^{\mathrm{a}}\end{array}$ & & & & - Benefits & Buyer-supplier & Dyadic & $\begin{array}{l}\text { Multiple- } \\
\text { case study }\end{array}$ & $\begin{array}{l}\text { Automotive } \\
\text { industry }\end{array}$ & Turkey & $\begin{array}{l}\text { chain management } \\
\text { and organizational } \\
\text { performance. } \\
\text { Social capital } \\
\text { facilities supplier } \\
\text { relationship learning. }\end{array}$ \\
\hline 68 & $\begin{array}{l}\text { Wu and Chiu } \\
\text { (2018) }\end{array}$ & $\checkmark$ & $\checkmark$ & $\checkmark$ & - Benefits & $\begin{array}{l}\text { Focal company- } \\
\text { supply chain } \\
\text { partners }\end{array}$ & $\begin{array}{l}206 \text { focal } \\
\text { company }\end{array}$ & Survey & $\begin{array}{l}\text { Multiple } \\
\text { industries }\end{array}$ & Taiwan & $\begin{array}{l}\text { Only SC positively } \\
\text { influences supply } \\
\text { chain collaboration, } \\
\text { which in turn } \\
\text { improve the focal } \\
\text { firm performance. }\end{array}$ \\
\hline 69 & $\begin{array}{l}\text { Yu and Huo } \\
\text { (2018) }\end{array}$ & $\checkmark$ & & & $\begin{array}{l}\text { - Antecedents } \\
\text { - Benefits }\end{array}$ & Buyers-supplier & 308 buyers & Survey & $\begin{array}{l}\text { Multiple } \\
\text { industries }\end{array}$ & China & $\begin{array}{l}\text { Internal RC positively } \\
\text { influences supplier } \\
\text { RC, which in turn } \\
\text { improves supplier } \\
\text { quality integration, } \\
\text { internal quality } \\
\text { integration, and } \\
\text { customer quality } \\
\text { integration. }\end{array}$ \\
\hline 70 & $\begin{array}{l}\text { Zimmermann, } \\
\text { Oshri, Lioliou, } \\
\text { and Gerbasi } \\
\text { (2018) }\end{array}$ & $\checkmark$ & $\checkmark$ & $\checkmark$ & - Benefits & Buyer-supplier & 150 buyers & Survey & $\begin{array}{l}\text { Multiple } \\
\text { industries }\end{array}$ & $\begin{array}{l}\text { Across } \\
\text { countries }\end{array}$ & $\begin{array}{l}\text { Social capital } \\
\text { dimensions facilitate } \\
\text { knowledge sharing. }\end{array}$ \\
\hline
\end{tabular}

Note: $\mathrm{R}=$ Relational; $\mathrm{C}=$ Cognitive; $\mathrm{S}=$ Structural; N/A = Not Applicable; NS = Not Specified.

a Social capital is treated as unidimensional construct.

\section{References}

Adler, P. S., \& Kwon, S. W. (2002). Social capital: Prospects for a new concept. Academy of Management Review, 27(1), 17-40.

Alghababsheh, M., \& Gallear, D. (2020). Socially sustainable supply chain management and suppliers' social performance: The role of social capital. Journal of Business Ethics, 1-21.

Alghababsheh, M., Gallear, D., \& Rahman, M. (2018). Balancing the scales of justice: Do perceptions of buyers' justice drive suppliers' social performance? Journal of Business Ethics, 1-26.

Ataseven, C., Nair, A., \& Ferguson, M. (2018). An examination of the relationship between intellectual capital and supply chain integration in humanitarian aid organizations: A survey-based investigation of food banks. Decision Sciences, 49(5), 827-862.

*Autry, C. W., \& Griffis, S. E. (2008). Supply chain capital: The impact of structural and relational linkages on firm execution and innovation. Journal of Business Logistics, 29 (1), 157-173.

Awaysheh, A., \& Klassen, R. D. (2010). The impact of supply chain structure on the use of supplier socially responsible practices. International Journal of Operations \& Production Management, 30(12), 1246-1268.

Baker, W. E. (1990). Market networks and corporate behavior. American Journal of Sociology, 96(3), 589-625.

Benton, W. C., \& Maloni, M. (2005). The influence of power driven buyer/seller relationships on supply chain satisfaction. Journal of Operations Management, 23(1), $1-22$.

*Bernardes, E. S. (2010). The effect of supply management on aspects of social capital and the impact on performance: A social network perspective. Journal of Supply Chain Management, 46(1), 45-55.

*Blonska, A., Storey, C., Rozemeijer, F., Wetzels, M., \& de Ruyter, K. (2013). Decomposing the effect of supplier development on relationship benefits: The role of relational capital. Industrial Marketing Management, 42(8), 1295-1306.

Bourdieu, P. (1986). The forms of capital. In J. G. Richardson (Ed.), Handbook of theory and research for the sociology of education (pp. 241-258). New York: Greenwood.

Burt, R. (1992). Structural holes: The social structure of competition. Cambridge, MA: Harvard University Press.

Burt, R. S. (1997). The contingent value of social capital. Administrative Science Quarterly, 42(2), 339-365.

Burt, R. S. (2000). The network structure of social capital. Research in Organizational Behavior, 22, 345-423.

\footnotetext{
* Articles included in the review.
}

*Carey, S., \& Lawson, B. (2011). Governance and social capital formation in buyersupplier relationships. Journal of Manufacturing Technology Management, 22(2), $152-170$.

*Carey, S., Lawson, B., \& Krause, D. R. (2011). Social capital configuration, legal bonds and performance in buyer-supplier relationships. Journal of Operations Management, 29(4), 277-288.

*Chang, K. H., \& Gotcher, D. F. (2007). Safeguarding investments and creation of transaction value in asymmetric international subcontracting relationships: The role of relationship learning and relational capital. Journal of World Business, 42(4), $477-488$.

*Chang, M. L., Cheng, C. F., \& Wu, W. Y. (2012). How buyer-seller relationship quality influences adaptation and innovation by foreign MNCs' subsidiaries. Industrial Marketing Management, 41(7), 1047-1057.

Chartered Association of Business Schools. (2018). Academic Journal Guide. https://ch arteredabs.org/academic-journal-guide-2018/. Retrieved August 25, 2019.

*Cho, M., Bonn, M. A., Giunipero, L., \& Jaggi, J. S. (2017). Contingent effects of close relationships with suppliers upon independent restaurant product development: A social capital perspective. International Journal of Hospitality Management, 67, $154-162$.

*Chou, T. C., Chen, J. R., \& Pan, S. L. (2006). The impacts of social capital on information technology outsourcing decisions: A case study of a Taiwanese high-tech firm. International Journal of Information Management, 26(3), 249-256.

Coleman, J. S. (1988). Social capital in the creation of human capital. American Journal of Sociology, 94, S95-S120.

*Cousins, P. D., Handfield, R. B., Lawson, B., \& Petersen, K. J. (2006). Creating supply chain relational capital: The impact of formal and informal socialization processes. Journal of Operations Management, 24(6), 851-863.

David, R. J., \& Han, S. K. (2004). A systematic assessment of the empirical support for transaction cost economics. Strategic Management Journal, 25(1), 39-58.

*Erridge, A., \& Greer, J. (2002). Partnerships and public procurement: Building social capital through supply relations. Public Administration, 80(3), 503-522.

*Fan, Y., \& Stevenson, M. (2018). Reading on and between the lines: Risk identification in collaborative and adversarial buyer-supplier relationships. Supply Chain Management: An International Journal., 23(4), 351-376.

Flynn, B., Pagell, M., \& Fugate, B. (2018). Survey research design in supply chain management: The need for evolution in our expectations. Journal of Supply Chain Management, 54(1), 1-15.

French, J. R., \& Raven, B. (1959). The bases of social power. In C. Dorwin (Ed.), Studies in social power (pp. 150-167). Ann Arbor: University of Michigan Press.

Fukuyama, F. (2001). Social capital, civil society and development. Third World Quarterly, 22(1), 7-20.

*Gelderman, C. J., Semeijn, J., \& Mertschuweit, P. P. (2016). The impact of social capital and technological uncertainty on strategic performance: The supplier perspective. Journal of Purchasing and Supply Management, 22(3), 225-234. 
Granovetter, M. (1992). Economic institutions as social constructions: A framework for analysis. Acta Sociologica, 35(1), 3-11.

*Grawe, S. J., Daugherty, P. J., \& Dant, R. P. (2012). Logistics service providers and their customers: Gaining commitment through organizational implants. Journal of Business Logistics, 33(1), 50-63.

Greenhalgh, T., \& Peacock, R. (2005). Effectiveness and efficiency of search methods in systematic reviews of complex evidence: Audit of primary sources. British Medical Journal, 331, 1064-1065.

*Hammervoll, T. (2011). Honeymoons in supply chain relationships: The effects of financial capital, social capital and psychological commitment. The International Journal of Logistics Management, 22(2), 264-279.

*Handoko, I., Bresnen, M., \& Nugroho, Y. (2018). Knowledge exchange and social capital in supply chains. International Journal of Operations \& Production Management, 38(1), 90-108.

*Hartmann, E., \& Herb, S. (2014). Opportunism risk in service triads-a social capital perspective. International Journal of Physical Distribution \& Logistics Management, 44 (3), 242-256.

*Horn, P., Scheffler, P., \& Schiele, H. (2014). Internal integration as a pre-condition for external integration in global sourcing: A social capital perspective. International Journal of Production Economics, 153, 54-65.

*Huikkola, T., Ylimäki, J., \& Kohtamäki, M. (2013). Joint learning in R\&D collaborations and the facilitating relational practices. Industrial Marketing Management, 42(7), 1167-1180.

*Hung, S. W., Chen, P. C., \& Chung, C. F. (2014). Gaining or losing? The social capital perspective on supply chain members' knowledge sharing of green practices. Technology Analysis \& Strategic Management, 26(2), 189-206.

Inkpen, A. C., \& Tsang, E. W. (2005). Social capital, networks, and knowledge transfer. Academy of Management Review, 30(1), 146-165.

Jalali, S., \& Wohlin, C. (2012). Systematic literature studies: Database searches vs. In Backward snowballing, in international conference on empirical software engineering and measurement (pp. 29-38). Lund, Sweden: ACM.

*Jean, R., Kim, D., \& Bello, D. C. (2017). Relationship-based product innovations: Evidence from the global supply chain. Journal of Business Research, 80, 127-140.

*Jia, F., Rutherford, C., \& Lamming, R. (2016). Cultural adaptation and socialisation between Western buyers and Chinese suppliers: The formation of a hybrid culture. International Business Review, 25(6), 1246-1261.

Johnsen, R. E., \& Lacoste, S. (2016). An exploration of the "dark side" associations of conflict, power and dependence in customer-supplier relationships. Industrial Marketing Management, 59, 76-95.

*Johnson, N., Elliott, D., \& Drake, P. (2013). Exploring the role of social capital in facilitating supply chain resilience. Supply Chain Management: An International Journal, 18(3), 324-336.

Kale, P., Singh, H., \& Perlmutter, H. (2000). Learning and protection of proprietary assets in strategic alliances: Building relational capital. Strategic Management Journal, 21 (3), 217-237.

Ketchen, D. J., Jr., Craighead, C. W., \& Cheng, L. (2018). Achieving research design excellence through the pursuit of perfection: Toward strong theoretical calibration. Journal of Supply Chain Management, 54(1), 16-22.

*Kim, K. K., Umanath, N. S., Kim, J. Y., Ahrens, F., \& Kim, B. (2012). Knowledge complementarity and knowledge exchange in supply channel relationships. International Journal of Information Management, 32(1), 35-49.

*Kim, K. T., Lee, J. S., \& Lee, S. Y. (2017). The effects of supply chain fairness and the buyer's power sources on the innovation performance of the supplier: A mediating role of social capital accumulation. Journal of Business \& Industrial Marketing, 32(7), 987-997.

*Kohtamäki, M., \& Bourlakis, M. (2012). Antecedents of relationship learning in supplier partnerships from the perspective of an industrial customer: The direct effects model. Journal of Business \& Industrial Marketing, 27(4), 299-310.

*Kohtamäki, M., Partanen, J., \& Möller, K. (2013). Making a profit with R\&D services-The critical role of relational capital. Industrial Marketing Management, 42 (1), 71-81.

*Kohtamäki, M., Vesalainen, J., Henneberg, S., Naudé, P., \& Ventresca, M. J. (2012) Enabling relationship structures and relationship performance improvement: The moderating role of relational capital. Industrial Marketing Management, 41(8), 1298-1309.

Kostova, T., \& Roth, K. (2003). Social capital in multinational corporations and a micromacro model of its formation. Academy of Management Review, 28(2), 297-317.

*Krause, D. R., Handfield, R. B., \& Tyler, B. B. (2007). The relationships between supplier development, commitment, social capital accumulation and performance improvement. Journal of Operations Management, 25(2), 528-545.

*Kulangara, N. P., Jackson, S. A., \& Prater, E. (2016). Examining the impact of socialization and information sharing and the mediating effect of trust on innovation capability. International Journal of Operations \& Production Management, 36(11), 1601-1624.

Kwon, S. W., \& Adler, P. S. (2014). Social capital: Maturation of a field of research. Academy of Management Review, 39(4), 412-422.

Leana, C. R., \& Buren, H. J. (1999). Organizational social capital and employment practices. Academy of Management Review, 24(3), 538-555.

*Lawson, B., Tyler, B. B., \& Cousins, P. D. (2008). Antecedents and consequences of social capital on buyer performance improvement. Journal of Operations Management, 26(3), 446-460.

*Lee, C. H., \& Ha, B. C. (2018). The impact of buyer-supplier relationships' social capital on bi-directional information sharing in the supply chain. Journal of Business \& Industrial Marketing, 33(3), 325-336.

Lee, R. (2009). Social capital and business and management: Setting a research agenda. International Journal of Management Reviews, 11(3), 247-273.
*Lee, S. Y. (2015). The effects of green supply chain management on the supplier's performance through social capital accumulation. Supply Chain Management: An International Journal, 20(1), 42-55.

*Leem, B. H., \& Rogers, K. J. (2017). The moderating effect of supply chain role on the relationship between social capital and performance. International Journal of Services and Operations Management, 26(1), 18-48.

*Li, L. Y. (2010). Antecedents of principal-Agent relationship value: The differential impact of social capital and dynamic learning factors. Journal of Marketing Channels, 17(4), 313-338.

*Li, Y., Ye, F., \& Sheu, C. (2014). Social capital, information sharing and performance: Evidence from China. International Journal of Operations \& Production Management, 34(11), 1440-1462.

Lin, N. (2001). Building a network theory of social capital. In N. Lin, K. Cook, \& R. S. Burt (Eds.), Social capital: Theory and research (pp. 3-30). New York: Aldine de Gruyter.

*Lioliou, E., \& Zimmermann, A. (2015). Vendor opportunism in IT outsourcing: A TCE and social capital perspective. Journal of Information Technology, 30(4), 307-324.

Luo, Y., Liu, Y., Yang, Q., Maksimov, V., \& Hou, J. (2015). Improving performance and reducing cost in buyer-supplier relationships: The role of justice in curtailing opportunism. Journal of Business Research, 68(3), 607-615.

Maloni, M., \& Benton, W. C. (2000). Power influences in the supply chain. Journal of Business Logistics, 21(1), 49-74.

Miemczyk, J., Johnsen, T. E., \& Macquet, M. (2012). Sustainable purchasing and supply management: A structured literature review of definitions and measures at the dyad, chain and network levels. Supply Chain Management: An International Journal, 17(5), 478-496.

*Min, S., Kim, S. K., \& Chen, H. (2008). Developing social identity and social capital for supply chain management. Journal of Business Logistics, 29(1), 283-304.

*Miocevic, D. (2016). The antecedents of relational capital in key exporter-importer relationships: An institutional perspective. International Marketing Review, 33(2), 196-218.

Nabi, M. N. U., Khan, E. A., Hasan, S. M., \& Mahmud, A. (2017). Social capital and product quality: a study of shrimp value chain in Bangladesh. International Journal of Value Chain Management, 8(3), 191-206.

Nahapiet, J., \& Ghoshal, S. (1998). Social capital, intellectual capital, and the organizational advantage. Academy of Management Review, 23(2), 242-266.

Narasimhan, R., Narayanan, S., \& Srinivasan, R. (2013). An investigation of justice in supply chain relationships and their performance impact. Journal of Operations Management, 31(5), 236-247.

Oh, H., Labianca, G., \& Chung, M. H. (2006). A multilevel model of group social capital. Academy of Management Review, 31(3), 569-582.

Payne, G. T., Moore, C. B., Griffis, S. E., \& Autry, C. W. (2011). Multilevel challenges and opportunities in social capital research. Journal of Management, 37(2), 491-520.

Pena-López, J. A., \& Sánchez-Santos, J. M. (2017). Individual social capital: Accessibility and mobilization of resources embedded in social networks. Social Networks, 49, $1-11$.

*Petersen, K. J., Handfield, R. B., Lawson, B., \& Cousins, P. D. (2008). Buyer dependency and relational capital formation: The mediating effects of socialization processes and supplier integration. Journal of Supply Chain Management, 44(4), 53-65.

Pillai, K. G., Hodgkinson, G. P., Kalyanaram, G., \& Nair, S. R. (2017). The negative effects of social capital in organizations: A review and extension. International Journal of Management Reviews, 19(1), 97-124.

Portes, A. (1998). Social capital: Its origins and applications in modern sociology. Annual Review of Sociology, 24(1), 1-24.

*Preston, D. S., Chen, D. Q., Swink, M., \& Meade, L. (2017). Generating supplier benefits through buyer-enabled knowledge enrichment: A social capital perspective. Decision Sciences, 48(2), 248-287.

*Presutti, M., Boari, C., \& Fratocchi, L. (2016). The evolution of inter-organisational social capital with foreign customers: Its direct and interactive effects on SMEs' foreign performance. Journal of World Business, 51(5), 760-773.

Putnam, R. D. (1993). The prosperous community: Social capital and public life. American Prospect, 13, 35-42.

Putnam, R. D. (1995). Bowling alone: America's declining social capital. Journal of Democracy, 6(1), 65-78.

*Qian, L., Yang, P., \& Xue, J. (2018). Hindering or enabling structural social capital to enhance buyer performance? The role of relational social capital at two levels in China. Journal of Business-to-Business Marketing, 25(3), 213-231.

Robison, L. J., Schmid, A. A., \& Siles, M. E. (2002). Is social capital really capital? Review of Social Economy, 60(1), 1-21.

*Roden, S., \& Lawson, B. (2014). Developing social capital in buyer-supplier relationships: The contingent effect of relationship-specific adaptations. International Journal of Production Economics, 151, 89-99.

*Roh, J. A., Whipple, J. M., \& Boyer, K. K. (2013). The effect of single rater bias in multistakeholder research: A methodological evaluation of buyer-supplier relationships. Production and Operations Management, 22(3), 711-725.

Rousseau, D. M., Manning, J., \& Denyer, D. (2008). Evidence in management and organizational science: Assembling the field's full weight of scientific knowledge through syntheses. The Academy of Management Annals, 2(1), 475-515.

*Schiele, H., Ellis, S. C., Eßig, M., Henke, J. W., \& Kull, T. J. (2015). Managing supplier satisfaction: Social capital and resource dependence frameworks. Australasian Marketing Journal, 23(2), 132-138.

*Shou, Y., Hu, W., \& Xu, Y. (2018). Exploring the role of intellectual capital in supply chain intelligence integration. Industrial Management \& Data Systems, 118(5), 1018-1032.

Siemsen, E., Roth, A. V., \& Balasubramanian, S. (2008). How motivation, opportunity, and ability drive knowledge sharing: The constraining-factor model. Journal of Operations Management, 26(3), 426-445. 
*Son, B. G., Kocabasoglu-Hillmer, C., \& Roden, S. (2016). A dyadic perspective on retailer-supplier relationships through the lens of social capital. International Journal of Production Economics, 178, 120-131.

Stolze, H. J., Mollenkopf, D. A., Thornton, L., Brusco, M. J., \& Flint, D. J. (2018). Supply chain and marketing integration: Tension in frontline social networks. Journal of Supply Chain Management, 54(3), 3-21.

*Sukoco, B. M., Hardi, H., \& Qomariyah, A. (2018). Social capital, relational learning, and performance of suppliers. Asia Pacific Journal of Marketing and Logistics, 30(2), 417-437.

*Tipu, S. A. A., \& Fantazy, K. (2018). Exploring the relationships of strategic entrepreneurship and social capital to sustainable supply chain management and organizational performance. International Journal of Productivity and Performance Management, 67(9), 2046-2070.

Tranfield, D., Denyer, D., \& Smart, P. (2003). Towards a methodology for developing evidence-informed management knowledge by means of systematic review. British Journal of Management, 14(3), 207-222.

Tsai, W., \& Ghoshal, S. (1998). Social capital and value creation: The role of intrafirm networks. Academy of Management Journal, 41(4), 464-476.

*Tsai, Y. H., Joe, S. W., Ding, C. G., \& Lin, C. P. (2013). Modeling technological innovation performance and its determinants: An aspect of buyer-seller social capital. Technological Forecasting and Social Change, 80(6), 1211-1221.

*Tseng, C. H., \& Chen, L. T. (2014). Determinants of subsidiary's technological capability-examining the roles of subsidiary-local supplier linkage. Journal of Business \& Industrial Marketing, 29(5), 374-386.

*Unal, B., \& Donthu, N. (2014). Role of absorptive capabilities in outsourcing the headquarters selling task in the United States. Industrial Marketing Management, 43 (6), 1079-1084.

*Uzunca, B. (2018). Biological children versus stepchildren: Interorganizational learning processes of spinoff and nonspinoff suppliers. Journal of Management, 44(8), 3258-3287.

Uzzi, B. (1996). The sources and consequences of embeddedness for the economic performance of organizations: The network effect. American Sociological Review, 61 (4), 674-698.

*Verwaal, E. (2017). Global outsourcing, explorative innovation and firm financial performance: A knowledge-exchange based perspective. Journal of World Business, 52 (1), 17-27.

*Villena, V. H., \& Craighead, C. W. (2017). On the same page? How asymmetric buyer-supplier relationships affect opportunism and performance. Production and Operations Management, 26(3), 491-508.
*Villena, V. H., Revilla, E., \& Choi, T. Y. (2011). The dark side of buyer-supplier relationships: A social capital perspective. Journal of Operations Management, 29(6), 561-576.

*Wang, L., \& Li, J. (2017). The antecedents and innovation outcomes of firms' absorptive capacity in global buyer-supplier relationships. The Journal of Technology Transfer, 42(6), 1407-1430.

*Wang, L., Terziovski, M., Jiang, F., \& Li, J. (2017). The effect of social capital on local suppliers' exploitative and exploratory learning in global buyer-supplier relationships: The moderating role of contract specificity. R\&D Management, 47(4), 654-668.

*Wang, Q., Li, J. J., Ross, W. T., \& Craighead, C. W. (2013). The interplay of drivers and deterrents of opportunism in buyer-supplier relationships. Journal of the Academy of Marketing Science, 41(1), 111-131.

Webster, J., \& Watson, R. T. (2002). Analyzing the past to prepare for the future: Writing a literature review. MIS Quarterly, xiii-xxiii.

*Whipple, J. M., Wiedmer, R., \& Boyer, K. (2015). A dyadic investigation of collaborative competence, social capital, and performance in buyer-supplier relationships. Journal of Supply Chain Management, 51(2), 3-21.

*Wiengarten, F., Singh, P. J., Fynes, B., \& Nazarpour, A. (2017). Impact of mass customization on cost and flexiblity performances: The role of social capital. Operations Management Research, 10(3-4), 137-147.

*Wu, L., \& Chiu, M. L. (2018). Examining supply chain collaboration with determinants and performance impact: Social capital, justice, and technology use perspectives. International Journal of Information Management, 39, 5-19.

*Yang, J. (2009). The determinants of supply chain alliance performance: An empirical study. International Journal of Production Research, 47(4), 1055-1069.

*Yang, J., Wang, J., Wong, C. W., \& Lai, K. H. (2008). Relational stability and alliance performance in supply chain. Omega, 36(4), 600-608.

*Yim, B., \& Leem, B. (2013). The effect of the supply chain social capital. Industrial Management \& Data Systems, 113(3), 324-349.

*Yu, Y., \& Huo, B. (2018). Supply chain quality integration: Relational antecedents and operational consequences. Supply Chain Management: An International Journal, 23(3), 188-206.

*Zhang, M., Guo, H., \& Zhao, X. (2017). Effects of social capital on operational performance: Impacts of servitisation. International Journal of Production Research, 55 (15), 4304-4318.

*Zimmermann, A., Oshri, I., Lioliou, E., \& Gerbasi, A. (2018). Sourcing in or out: Implications for social capital and knowledge sharing. The Journal of Strategic Information Systems, 27(1), 82-100. 